\title{
Artemisinin-Type Drugs in Tumor Cell Death: Mechanisms, Combination Treatment with Biologics and Nanoparticle Delivery
}

\author{
Xinyu Zhou (D), Fengzhi Suo, Kristina Haslinger*(D) and Wim J. Quax*(D) \\ Department of Chemical and Pharmaceutical Biology, Groningen Research Institute of Pharmacy, \\ University of Groningen, Antonius Deusinglaan 1, 9713 AV Groningen, The Netherlands; \\ xinyu.zhou@rug.nl (X.Z.); f.suo@rug.nl (F.S.) \\ * Correspondence: k.haslinger@rug.nl (K.H.); w.j.quax@rug.nl (W.J.Q.)
}

\section{check for} updates

Citation: Zhou, X.; Suo, F.; Haslinger, K.; Quax, W.J. Artemisinin-Type Drugs in Tumor Cell Death: Mechanisms, Combination Treatment with Biologics and Nanoparticle Delivery. Pharmaceutics 2022, 14, 395. https://doi.org/10.3390/ pharmaceutics14020395

Academic Editors: Cristina Sánchez González, Juan Llopis and Lorenzo Rivas García

Received: 10 December 2021

Accepted: 7 February 2022

Published: 10 February 2022

Publisher's Note: MDPI stays neutral with regard to jurisdictional claims in published maps and institutional affiliations.

Copyright: (C) 2022 by the authors. Licensee MDPI, Basel, Switzerland. This article is an open access article distributed under the terms and conditions of the Creative Commons Attribution (CC BY) license (https:// creativecommons.org/licenses/by/ $4.0 /)$.

\begin{abstract}
Artemisinin, the most famous anti-malaria drug initially extracted from Artemisia annua L., also exhibits anti-tumor properties in vivo and in vitro. To improve its solubility and bioavailability, multiple derivatives have been synthesized. However, to reveal the anti-tumor mechanism and improve the efficacy of these artemisinin-type drugs, studies have been conducted in recent years. In this review, we first provide an overview of the effect of artemisinin-type drugs on the regulated cell death pathways, which may uncover novel therapeutic approaches. Then, to overcome the shortcomings of artemisinin-type drugs, we summarize the recent advances in two different therapeutic approaches, namely the combination therapy with biologics influencing regulated cell death, and the use of nanocarriers as drug delivery systems. For the former approach, we discuss the superiority of combination treatments compared to monotherapy in tumor cells based on their effects on regulated cell death. For the latter approach, we give a systematic overview of nanocarrier design principles used to deliver artemisinin-type drugs, including inorganic-based nanoparticles, liposomes, micelles, polymer-based nanoparticles, carbon-based nanoparticles, nanostructured lipid carriers and niosomes. Both approaches have yielded promising findings in vitro and in vivo, providing a strong scientific basis for further study and upcoming clinical trials.
\end{abstract}

Keywords: artemisinin; regulated cell death; combination treatment; nanoparticle delivery

\section{Introduction}

Nowadays, artemisinin (ART) and its derivatives offer the best protection against malaria. ART is a non-nitrogenous sesquiterpene lactone with a molecular formula of $\mathrm{C}_{15} \mathrm{H}_{22} \mathrm{O}_{5}$, which is derived from the Chinese plant Artemisia annua L. (also called sweet wormwood) [1,2]. The earliest record of using Artemisia annua L. as a drug (for treating hemorrhoids) was in a book named Wushi'er Bingfang (Prescriptions for Fifty-two Diseases) which was discovered in the Mawangdui tomb and was written around 215 BCE or even earlier [3,4]. Afterward, the plant was described as a malaria treatment in Zhou Hou Bei Ji Fang (Handbook of Prescriptions for Emergency, 326-341 CE) and Dan Xi Xin Fa (Danxi's Mastery of Medicine, 1347 CE) [5,6]. In 1967, as an international help for Vietnamese soldiers suffering from malaria during the Vietnam War, "Project 523" was initiated by the Peoples' Republic of China to research promising anti-malarial drugs [7]. Among all screened traditional Chinese medicines, realgar and artemisinin were two potential candidates with a 100\% inhibition rate to rodent malaria [8]. Due to the toxicity of realgar in clinical trials, research was focused on the extraction and structural optimization of artemisinin $[9,10]$.

The endoperoxide 1, 2, 4-trioxane bridge of ART was firstly identified by the Shanghai Institute of Organic Chemistry in 1975 [11,12]. It is cleaved by intracellular ferrous iron $\left(\mathrm{Fe}^{2+}\right)$ into reactive oxygen species (ROS), resulting in the death of parasites. More ART 
derivatives were synthesized with the inherent endoperoxide bridge and a lactone ring, exhibiting better solubility and potency [13]. Dihydroartemisinin (DHA) was the first artemisinin derivative synthesized through the sodium borohydride reduction of ART [14]. It also acts as an intermediate in the synthesis of the other derivatives [15,16]. Currently, DHA, artesunate (ATS), artemether (AM) and arteether (AE; also known as artemotil) are the four derivatives for clinical application [6] (Figure 1). The application of ART and its derivatives in malaria patients is rapid and effective, especially when used alongside other antimalarial drugs in artemisinin-based combination therapies (ACTs) [17,18].

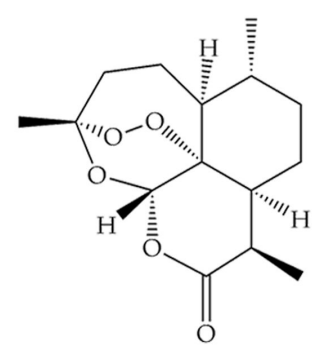

Artemisinin (ART)

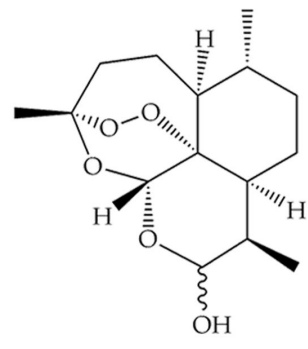

Dihydroartemisinin (DHA)

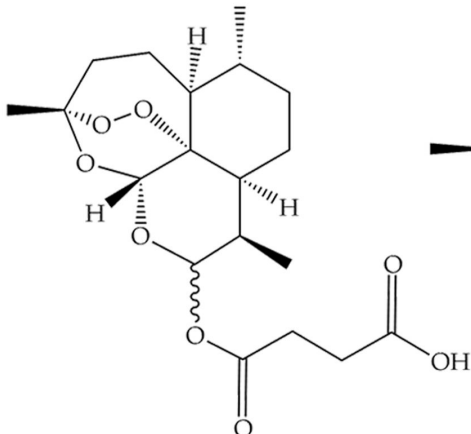

Artesunate (ATS)

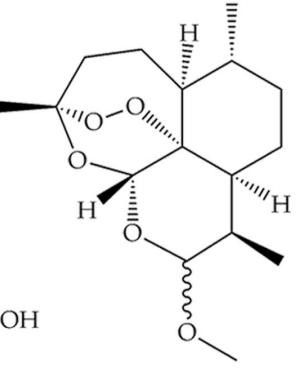

Artemether (AM)

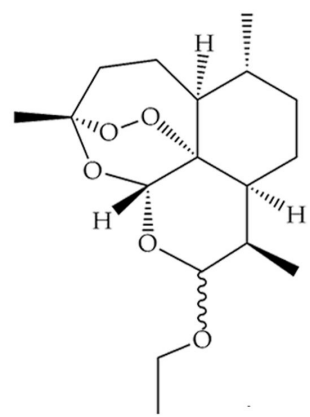

Arteether

(AE)

Figure 1. Artemisinin and four derivatives in clinical application.

In the early 1990s, the anti-tumor activity of ART-type drugs was discovered [19-21], making them also promising candidates for cancer therapy. Since then, their anti-tumor mechanisms have been widely studied in numerous cancer types. It has been proved that tumor cells are more susceptible to ART-type drugs than their normal counterparts, because of their higher intracellular iron capacity and tumor microenvironment [22,23]. When iron cleaves the endoperoxide bridge of ART-type drugs, the generated ROS leads to various cellular events, such as DNA damage, cell cycle arrest and cell death [5,24]. ART-type drug-induced cell death was first addressed as apoptosis. However, more studies demonstrated that ART-type drugs not only induce apoptosis but also other types of regulated cell death $(\mathrm{RCD})$. Here, we provide a timely summary and discussion of research in the last ten years on the influence of ART-type drugs on different RCD pathways in tumor cells (Section 2). On this basis, we review the current combination therapies of ART-type drugs with signaling pathway-related proteins or antibodies to establish enhanced efficacy (Section 3). To overcome the shortcomings of ART-type drugs, such as low solubility, low bioavailability, short plasma half-life and chronic toxicity, ART-related nanocarrier delivery technology came into the picture and proved to be more tumorspecific with improved effectiveness. Therefore, we recap the formation and efficacy of ART-type drugs-loaded nanoparticles (NPs) according to the recently published research (Section 4). We hope this review can serve as a comprehensive overview of the cell deathinducing mechanism and promising combination treatment as well as the newest delivery approaches for ART-type drugs.

\section{Artemisinin and Regulated Cell Death in Cancer}

Artemisinin as a potential anti-tumor drug has been investigated for decades. Considerable effort was made to understand the mechanism of ART-induced cell death, in which, RCD drew major attention. RCD is a lethal process resulting in the elimination of unwanted cells through built-in effects of physiological programs (referred to as programmed cell death), or cell death induced by the intracellular or extracellular stress [25,26]. Among all classified RCD types, ART-type drug-induced cell death has been linked to apoptosis, ferroptosis, autophagy, necroptosis and pyroptosis as reviewed in the following sections. 


\subsection{Apoptosis}

Apoptosis is an irreversible RCD with certain biochemical feature changes, such as the caspase cascade activation, DNA fragmentation, and the externalization of internal phosphatidylserine [27-29]. Cell shrinkage and pyknosis can be observed in early-stage apoptotic cells, followed by the formation and release of the apoptotic body in the late stage [30].

As of today, the extrinsic and intrinsic pathways are the two main apoptosis pathways, and the perforin/granzyme pathway as a T-cell mediated signal route has also been defined. The extrinsic pathway is initiated through interactions of ligands with transmembrane receptors of the tumor necrosis factor (TNF) superfamily, such as TNF- $\alpha /$ TNFR1, FasL/Fas, TRAIL/DR4 or DR5, VEGI/DR3 and TWEAK/Fn14 [31-37]. The ligand binds to the receptor to recruit adaptor proteins (FADD, TRADD) to activate the caspase cascade and trigger apoptosis [38-40]. As a counterbalance to this process, FLICE-like Inhibitory Protein (c-FLIP) competitively binds to FADD or procaspase-8 to prevent the death-inducing signaling complex (DISC) formation and inhibit apoptosis [41]. The intrinsic pathway is normally initiated by cell stress (ROS/radiation, etc.) or insufficient activation of caspase-8 required for the extrinsic pathway [42]. Due to pro-apoptotic signaling, the mitochondrial membrane is permeabilized, which results in the release of cytochrome $C$ and the formation of the apoptosome, leading to the activation of caspase- 9 and the following caspase cascade [43]. The perforin/granzyme pathway is induced by the secretion of perforin and granzymes from multiple immune cells to impose sanctions against infected or transformed cells [44]. By entering the targeted cells through the perforin-formed pores, granzyme $\mathrm{B}$ induces caspase-3-related apoptosis, while granzyme A leads to DNA fragmentation [45].

ART-type drug-induced apoptosis was initially reported in human leukemic cells by Efferth et al. in 1996 [46]. Later, other studies indicated that ART-type drugs trigger tumor cells to undergo apoptosis through regulating numerous factors within apoptosis pathways (Table 1; Figure 2, green part I) [47,48]. In the extrinsic pathway, DR5 expression is upregulated by ATS and DHA in colon cancer cell lines [49]. However, Ilamathi et al. found that ATS mainly induces DR4 but not DR5 expression in the hepatocellular carcinoma cell line HepG2, indicating the complex impacts of ART-type drugs on apoptosis pathways [50]. Besides, ART also inhibits the expression of cellular anti-apoptotic c-FLIP [51]. Based on the mentioned effects of ART-type drugs, caspase- 8 and caspase- 3 are inevitably upregulated to induce apoptosis and DNA damage $[52,53]$.

For the intrinsic apoptosis pathway, it has been shown that the ROS accumulation induced by ART-type drugs directly influences the signal transduction within the pathway. However, the convoluted signaling network of this pathway results in a diversified effect of the ART-type drugs. It was shown that the expression of some pro-apoptotic proteins, such as Bax [54], Noxa [55], Puma [56], Bim and truncated Bid (tBid) [57], is upregulated to promote apoptosis. Furthermore, ART-type drugs also suppress the expression of multiple anti-apoptotic proteins, including Bcl-2 [58], Bcl-xL [59] and Mcl-1 [60]. Because of the altered and imbalanced expression of pro- and anti-apoptotic proteins under treatment, mitochondrial outer membrane permeabilization (MOMP) is induced [61], which leads to the release of cytochrome $C$ [58] and activation of caspase-9 [54].

For the perforin/granzyme pathway, it has been reported that ART-type drugs induce granzyme B expression in $\gamma \delta \mathrm{T}$ cells which derived from the peripheral blood mononuclear cells and cytotoxic T lymphocytes (CTLs), indicating that ART-type drugs directly act on cancer cells with concomitant effects on immune cells to induce tumor cell to undergo apoptosis [62,63].

Apoptosis induced by ART-type drugs has been studied for 30 years. Their effects on the apoptosis-related proteins have been fully analyzed and their potential in cancer treatment has been investigated. Apart from apoptosis, ART-type drugs have also been shown to induce other RCD pathways in tumor cells, which will be discussed below. 


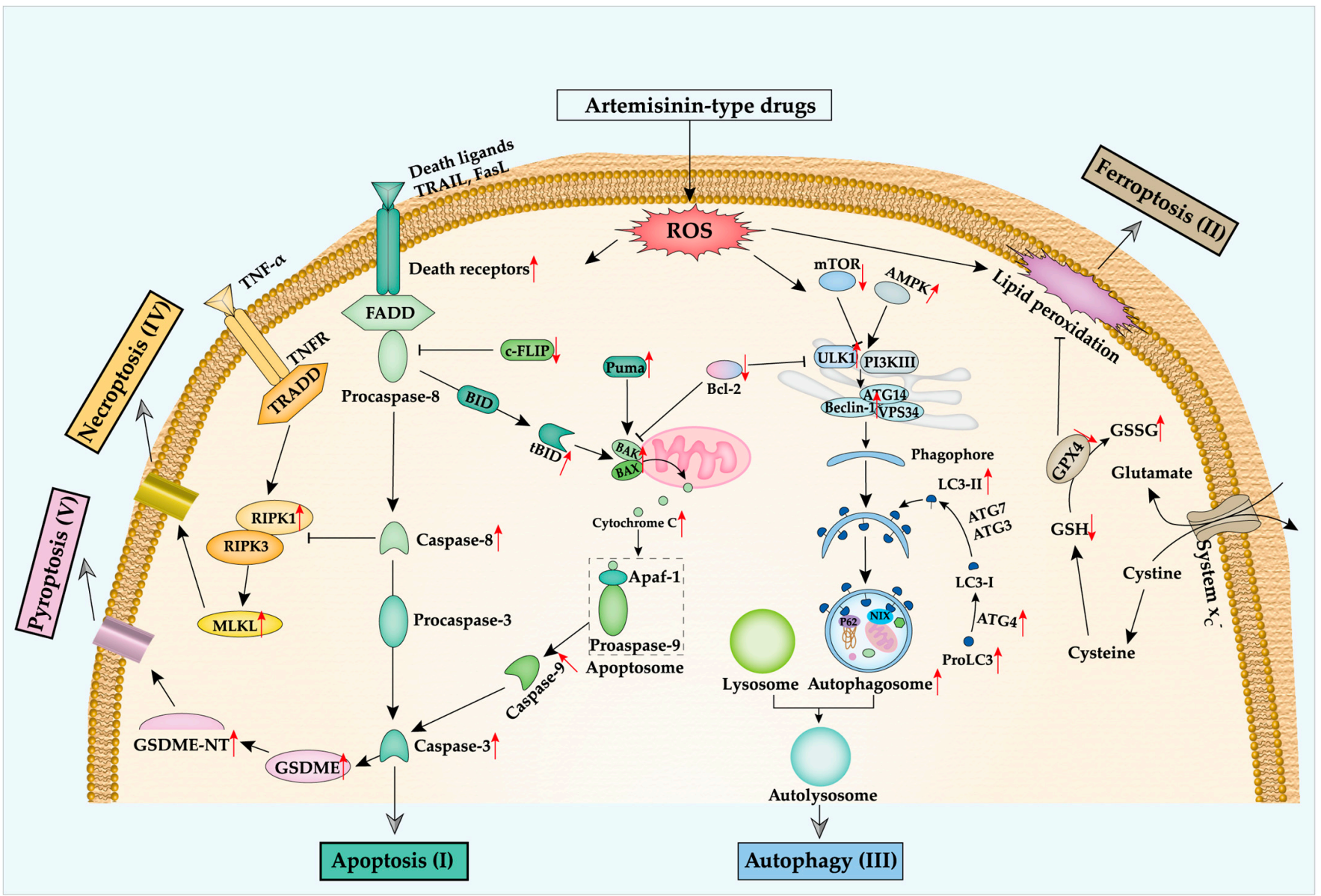

Figure 2. Artemisinin-type drugs influence several RCD pathways. The red arrows represent the upregulation or downregulation of certain key players on protein level. (I) ART-type drugs produce ROS resulting in increased expression of death receptors, and cleavage of caspase- 3 and caspase- 8 , and decreased c-FLIP expression, leading to stimulation of the extrinsic apoptosis pathway. Meanwhile, ROS itself also triggers the intrinsic apoptosis pathway by upregulating the expression of tBID, BAX/BAK, inducing the release of Cytochrome $\mathrm{C}$ to activate caspase-9. (II) ROS accumulation from ART-type drugs results in lipid peroxidation to induce ferroptosis. Besides, the disruption of the oxidative homeostasis maintaining system by ART-type drugs leads to downregulation of GPX4 expression. (III) The oxidative stress from ART-type drugs initiates the formation of the phagophore via activating the AMPK pathway and assembling the VPS34 complex, resulting in autophagy. ARTtype drugs also increase MLKL pore formation to induce necroptosis (IV), or GSDME-NT pore formation to induce pyroptosis $(\mathbf{V})$.

Table 1. List of studies from the last 10 years investigating the effect of ART-type drugs related to apoptosis in cancer cells with information on the model systems used, the ART-type drugs tested and the major findings of the study.

\begin{tabular}{|c|c|c|c|}
\hline Cell Lines; Cancer & Drugs & Effects & Ref. \\
\hline $\begin{array}{l}\text { HOS, MG-63, U-2 OS, } \\
\text { Saos-2; Osteosarcoma }\end{array}$ & DHA & 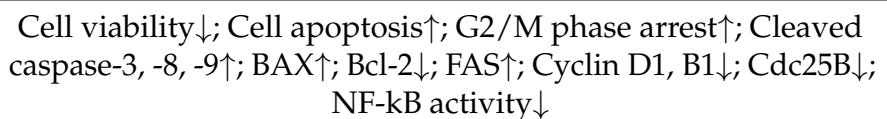 & $2011[52]$ \\
\hline $\begin{array}{c}\text { MCF-7, T47D, } \\
\text { MDA-MB-231; Breast cancer }\end{array}$ & ATS & $\begin{array}{l}\text { Cell death } \uparrow ; \text { ROS } \uparrow ; \text { DFO reduces ROS production and cell death; } \\
\text { LC3 puncta } \uparrow ; \text { LC3-II } \uparrow \text {; Cell death rescued by CQ and BafA1 }\end{array}$ & $2011[61]$ \\
\hline $\begin{array}{l}\text { G-361, A375, } \\
\text { LOX; Melanoma }\end{array}$ & DHA & $\begin{array}{c}\text { Cell apoptosis } \uparrow \text {; ROS } \uparrow \text {; Cell viability } \downarrow \text {; DFO reduces ROS } \\
\text { production and cell death; Transmembrane potential } \downarrow \text {; NOXA } \uparrow \text {; } \\
\text { CHOP } \uparrow ; \text { p-P53 } \uparrow\end{array}$ & 2012 [55] \\
\hline
\end{tabular}


Table 1. Cont.

\begin{tabular}{|c|c|c|c|}
\hline Cell Lines; Cancer & Drugs & Effects & Ref. \\
\hline T47D; Breast cancer & DHA & 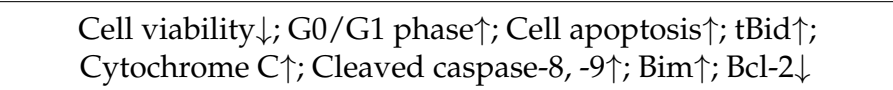 & 2013 [57] \\
\hline $\begin{array}{l}\text { Eca109, Ec9706; } \\
\text { Esophageal cancer }\end{array}$ & DHA & 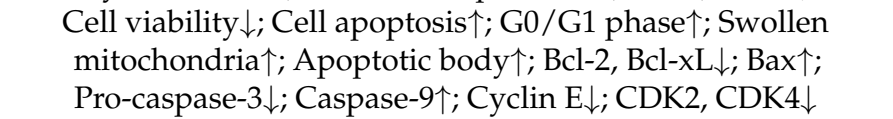 & 2013 [59] \\
\hline $\begin{array}{l}\text { SW1990, BxPC-3, PANC-1; } \\
\text { Pancreatic cancer. } \gamma \delta \text { T cell }\end{array}$ & DHA & $\begin{array}{l}\text { No influence on the ell viability of } \gamma \delta \mathrm{T} \text {; DHA-treated } \gamma \delta \text { T cell } \\
\text { reduces cancer cell viability; Increasing expression of perforin, } \\
\text { granzyme B, CD107a, IFN- } \gamma \text { from } \gamma \delta \text { T cell }\end{array}$ & 2013 [63] \\
\hline $\begin{array}{l}\text { HepG2, Huh-7, LO2; } \\
\text { Liver cancer }\end{array}$ & ART, ATS, DHA & $\begin{array}{c}\text { Cell viability } \downarrow \text {; Cell apoptosis } \uparrow ; \text { NAC and zVAD reduce cell } \\
\text { death; Chromatin condensation } \uparrow ; \text { ROS } \uparrow \text {; Transmembrane } \\
\text { potential } \downarrow ; \text { Caspase-3, -8, -9 activity } \uparrow ; \text { Cytochrome C releasing } \uparrow \\
\text { Bax, Bak, Bim } \uparrow \text {; Mcl- } 1 \downarrow\end{array}$ & $2015[60]$ \\
\hline Diverse cell lines & $\begin{array}{l}\mathrm{ART} \text { and } 4 \\
\text { derivatives }\end{array}$ & 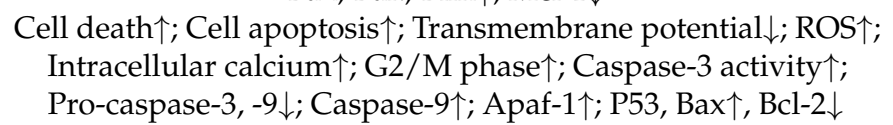 & $2017[54]$ \\
\hline $\begin{array}{l}\text { EJ-138, HTB-9; } \\
\text { Bladder cancer }\end{array}$ & DHA & $\begin{array}{l}\text { Cell viability } \downarrow ; \text { Cell apoptosis } \uparrow ; \text { Transmembrane potential } \downarrow ; \\
\text { ROS } \uparrow \text {; Caspase- } 3 \text { activity } \uparrow ; \text { Bax } \uparrow, B c l-2 \downarrow ; \text { Cytochrome } C \uparrow\end{array}$ & $2017[58]$ \\
\hline Diverse cell lines & ATS & $\begin{array}{c}\text { Cell apoptosis } \uparrow \text {; Lipid peroxidation } \uparrow ; \text { GRP78 } \uparrow ; \mathrm{CHOP} \uparrow ; \\
\text { PUMA } \uparrow ; \text { Tumor growth } \downarrow\end{array}$ & $2017[56]$ \\
\hline SK-Hep-1; Liver cancer & DHA & 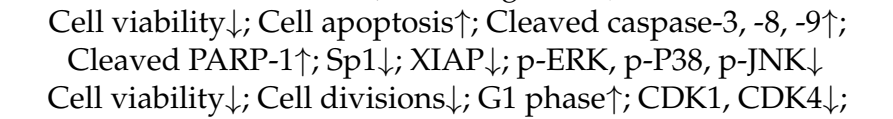 & 2018 [48] \\
\hline $\begin{array}{l}\text { SK-BR-3, MDA-MB-468, } \\
\text { MCF-7; Breast cancer }\end{array}$ & ATS & $\begin{array}{c}\text { CDC25C } \downarrow ; \text { Cyclin B, Cyclin D3 } \downarrow ; \mathrm{P} 21 \uparrow ; \text { Cell apoptosis } \uparrow ; \text { Cleaved } \\
\text { PARP-1 } \uparrow \text {; Caspases activation } \uparrow ; \text { Mitochondrial outer membrane } \\
\text { permeability } \uparrow ; \text { Cytochrome C, SMAC } \uparrow ; \operatorname{ROS} \uparrow\end{array}$ & 2019 [53] \\
\hline 4T1; Mouse breast cancer & ART & $\begin{array}{c}\text { Cell viability } \downarrow \text {; Cell apoptosis } \uparrow \text {; TGF- } \beta \downarrow \text {; Tumor growth } \downarrow \text {; Treg } \\
\text { and MDSC expansion } \downarrow ; \text { CD } 4+\text { IFN- } \gamma+\text { T cells and granzyme B+ } \\
\text { cytotoxic T lymphocytes } \uparrow\end{array}$ & 2019 [62] \\
\hline
\end{tabular}

Arrow "^" indicates an enhancing effect or upregulation; " $\downarrow$ " indicates a diminishing effect or downregulation; abbreviations used in the table are listed at the end of the manuscript.

\subsection{Ferroptosis}

ART-type drugs not only induce apoptosis but also promote ferroptosis in tumor cells. As a recently defined mechanism of $\mathrm{RCD}$, ferroptosis is characterized by iron accumulation and lipid peroxidation [64]. Morphologically, ferroptosis differs from apoptosis, necrosis, or autophagy, exhibiting small mitochondria with increased membrane density and fewer cristae, and it has a relatively intact cell membrane and normal nucleus [65]. Auto-oxidation or lipoxygenases (LOXs)-mediated oxidation of polyunsaturated fatty acids (PUFAs) leads to the production of lipid ROS and eventually triggers ferroptosis [66]. Within this process, glutathione peroxidase 4 (GPX4) is critical for regulating ferroptosis by reducing toxic lipid hydroperoxides to the corresponding alcohol by oxidizing glutathione (GSH) [67]. Besides, GSH is synthesized from glutamate and cysteine, the intracellular concentration of which is regulated by the amino acid antiporter system $x_{c}{ }^{-}$[68]. Thus, the blockage of system $\mathrm{x}_{\mathrm{C}}{ }^{-}$, the lack of GSH, or the inhibition of GPX4 abolishes the anti-oxidative functions and initiates canonical ferroptosis. Furthermore, the imbalance of the intracellular $\mathrm{Fe}^{3+}$ and $\mathrm{Fe}^{2+}$, or the accumulation of $\mathrm{Fe}^{2+}$ in the labile iron pool can stimulate ROS production and trigger non-canonical ferroptosis [69].

ART is known to kill parasites and cancer cells through the ROS which is generated by the cleavage of its endoperoxide bridge [70,71]. Meanwhile, the accumulation of ROS will trigger ferroptosis. Thus, more evidence was found to prove that ART-type drugs are capable of inducing ferroptosis and influencing ferroptosis-related proteins (Figure 2, brown part II). First of all, more ROS generation was observed upon treatment with ART-type drugs, not only in the cytoplasm but also in mitochondria and on lipid level [72,73]. Second, the expression of SLC7A11 and SLC3A2, which encode system $\mathrm{x}_{\mathrm{c}}{ }^{-}$, are downregulated by ART-type drugs to obstruct the glutamate and cysteine exchange [74]. Simultaneously, 
less GSH, more oxidized glutathione (Glutathione disulfide; GSSG), and reduced GPX4 are detected in the treated cells, which eliminates the pivotally anti-peroxidant system [75]. Lastly, direct interference with ROS formation or iron accumulation limits the effect of treatment with ART-type drugs. The iron chelator deferoxamine (DFO) can rescue cells from ART-type drug-induced ferroptosis [76]. Moreover, similar effects were observed in the cells treated with ROS scavenger Trolox [76] and N-acetyl-1-cysteine (NAC) [77], the ferroptosis inhibitor liproxstatin-1 (Lip-1) and ferrostatin-1 (Fer-1) [78], the lysosomal inhibitor bafilomycin A1 (BafA1) [79] (Table 2).

As a newly defined RCD type, ferroptosis is extremely relevant with ROS accumulation and iron dyshomeostasis. As we demonstrated above, ART-type drugs contribute ROS and induce ferroptosis in various tumor cells. However, there is still a lack of understanding of the mechanism of ferroptosis, for example, the exact role of lipid ROS in executing ferroptosis [80]. Here, we summarize the effects of ART-type drugs on the ferroptosis pathway (Table 2) and hope to provide potential therapeutic approaches for cancer treatment.

Table 2. List of studies from the last 10 years investigating the effect of ART-type drugs related to ferroptosis in cancer cells with information on the model systems used, the ART-type drugs tested and the major findings of the study.

\begin{tabular}{|c|c|c|c|}
\hline Cell Lines; Cancer & Drugs & Effects & Ref. \\
\hline Diverse cell lines & ART, 10 derivatives & $\begin{array}{l}\text { Artenimol induced cell death rescued by Fer-1 in } \\
\text { CCRF-CEM cell }\end{array}$ & $2015[81]$ \\
\hline $\begin{array}{l}\text { Panc-1, COLO357, AsPC-1, BxPC-3; } \\
\text { Pancreatic cancer }\end{array}$ & ATS & ROS $\uparrow$; Cell death rescued by DFO, trolox and Fer- 1 & $2015[76]$ \\
\hline $\begin{array}{l}\text { Head and neck squamous } \\
\text { cell carcinoma }\end{array}$ & DHA & $\begin{array}{c}\text { GPX } 4 \downarrow ; \text { Ras } \downarrow ; \text { P } 53 \downarrow ; \text { Bcl- } 2 \downarrow ; \text { Cell death rescued } \\
\text { by DFO }\end{array}$ & $2016[82]$ \\
\hline DAUDI, CA-46; Burkitt's Lymphoma & ATS & $\begin{array}{c}\text { Cell death rescued by DFO, Lip-1 and Fer- } 1 \text {; ATF } 4 \uparrow ; \\
\text { CHOP } \uparrow ; \text { CHAC } 1 \uparrow ; \text { Tumor growth } \downarrow\end{array}$ & 2019 [83] \\
\hline U251, U373; Patient-derived glioma & DHA & $\begin{array}{c}\text { Cell death } \uparrow ; \text { ROS and Malondialdehyde } \uparrow ; \mathrm{GSH} \downarrow ; \\
\text { GSSG } \uparrow ; \mathrm{CHOP} \uparrow ; \mathrm{HSPA} 5 \uparrow ; \mathrm{GPX} 4 \uparrow\end{array}$ & $2019[75]$ \\
\hline PaTU8988, AsPC-1; Pancreatic cancer & ATS & Cell death rescued by Fer-1; GRP78 $\uparrow$ & $2019[84]$ \\
\hline HL60, KG1, THP-1; Leukemia & DHA & $\begin{array}{c}\text { Cell viability } \downarrow \text {; Dysfunction of mitochondria; } \\
\text { Mitochondrial ROS } \uparrow \text {; Cytoplasm ROS } \uparrow \text {; p-AMPK } \uparrow \text {; } \\
\text { p-mTOR } \downarrow ; \text { Ferritin heavy chain (FTH) } \downarrow ; \text { GPX } \downarrow \text {; FTH } \\
\text { over-expression prevents DHA-induced ferroptosis; } \\
\text { Tumor growth } \downarrow\end{array}$ & 2019 [73] \\
\hline U87, A172; Glioblastoma & DHA & $\begin{array}{c}\text { Cell viability } \downarrow ; \text { Total ROS and lipid } \operatorname{ROS} \uparrow ; \text { HO- } 1 \uparrow ; \\
\text { GPX } 4 \downarrow ; \text { Mitochondrial ridges } \downarrow \text {; Bilayer membrane } \\
\text { density } \uparrow ; \text { Fer- } 1 \text { decreases ROS production and } \\
\text { inhibits cell death }\end{array}$ & $2020[72]$ \\
\hline MT-2, MT-4, HUT-102; Leukemia & ATS & $\begin{array}{c}\text { T-cell growth } \downarrow ; \text { ROS } \uparrow ; \text { Cell death rescued by Fer-1; } \\
\text { Tumor growth } \downarrow\end{array}$ & $2020[78]$ \\
\hline Diverse cell lines & ART ATS DHA AM & $\begin{array}{c}\text { Cell death } \uparrow ; \text { lipid ROS } \uparrow \text {; GSH } \downarrow \text {; Cell death rescued } \\
\text { by DFO or BafA1 }\end{array}$ & $2020[79]$ \\
\hline $\begin{array}{l}\text { U2932, SU-DHL2, SU-DHL4, } \\
\text { SU-DHL6, } 293 \text { T; Lymphoma }\end{array}$ & ATS & $\begin{array}{l}\text { Cell viability } \downarrow \text {; Colony formation } \downarrow \text {; GPX } 4 \downarrow \text {; FTH- } 1 \text {; } \\
\text { ROS and Malondialdehyde } \uparrow \text {; Cell death rescued by } \\
\text { Fer- } 1 \text {; p-STAT3 } \downarrow ; \text { Tumor growth } \downarrow \\
\text { Cell viability } \downarrow \text {; Lipid ROS and Malondialdehyde } \uparrow ;\end{array}$ & $2021[85]$ \\
\hline $\begin{array}{l}\text { Hep3B, PLC/PRF/5, Huh7, HepG2; } \\
\text { Primary liver cancer }\end{array}$ & DHA & $\begin{array}{c}\text { Iron content } \uparrow ; \mathrm{GSH} / \mathrm{GSSG} \downarrow ; \mathrm{GPX} 4 \downarrow ; \mathrm{SLC7A11} \text { and } \\
\text { SLC3A2 } \downarrow ; \mathrm{CHAC} \uparrow ; \text { Tumor growth } \downarrow ; \mathrm{p}-\mathrm{PERK} \text { and } \\
\text { IRE1- } \alpha \uparrow ; \mathrm{ATF} 4 \text { and ATF6 } \uparrow\end{array}$ & 2021 [74] \\
\hline $\begin{array}{l}\text { NCI-H1299, A549, LTEP-a-2, } \\
\text { NCI-H23, NCI-H358; Lung cancer }\end{array}$ & ART DHA & $\begin{array}{c}\text { Cell death } \uparrow ; \text { Cystine/glutamate transporter }(\mathrm{xCT}) \downarrow ; \\
\text { Cell death rescued by NAC }\end{array}$ & 2021 [77] \\
\hline
\end{tabular}




\subsection{Autophagy}

The role of autophagy (mainly macroautophagy here) in cancer is fundamentally a double-edged sword that can be a tumor suppressor or tumor protector. Thus, it is essential to understand the effects and mechanisms of ART-type drugs in inducing autophagy and the consequences in cancer cells. Autophagy is a catabolic process that degrades aggregated or long-lived proteins, damaged organelles, inactive pathogens in the lysosome [86]. The extracellular and intracellular stress, such as hypoxia, nutrient deprivation, growth factor depletion, ROS accumulation, and DNA damage, are responsible for the initiation of autophagy $[87,88]$. Multiple autophagy-related proteins (ATGs) assemble as vital complexes (ULK1 complex, PI3KIII complex, or PI3P binding complex) to initiate the phagophore formation, in which AMP-activated kinase (AMPK) acts as the activator and mammalian target of rapamycin (mTOR) as the suppressor. Meanwhile, Microtubule-associated protein 1A/1B-light chain 3 (LC3) is cleaved by ATG4 into LC3-I, which is further modified by ATG7 and ATG3 to conjugate with the lipid phosphatidylethanolamine (PE) to generate LC3-II (LC3-PE) [89]. Then, LC3-II will be incorporated into the pre-autophagosomal membranes [90,91]. Various autophagy receptors (P62, NBR1, Surf1, NIX/BNIP3L) are recruited to bind with LC3-II to recognize and engulf the targeted cargos to form the autophagosome. Finally, the matured double-membrane autophagosome fuses with the lysosome to form autolysosome and degrade the sequestered contents followed by the release of the vital cellular components [92].

ART-type drugs are proved to induce autophagy by the formation of LC3-puncta or the autophagosome (or acidic vesicular organelles) in numerous cancer cells (Figure 2, blue part III). ART-type drugs not only increase LC3-II expression but also trigger ULK1 phosphorylation and downregulate P62/SQSTM expression (Table 3). Besides, the activation of AMPK and inhibition of mTOR expression also indicates that ART-type drugs induce autophagy through AMPK signaling activation and AKT-mTOR signaling suppression $[93,94]$. Interestingly, the investigation of the crosstalk of autophagy and apoptosis shows inconclusive results: Jia et al. and Jiang et al. found that the autophagy inhibitors 3-Methyladenine (3MA) or Hydroxychloroquine sulfate (HCQ) promote ART-type druginduced apoptosis $[95,96]$; others found that the autophagy inhibitors Chloroquine (CQ), Spautin-1, BafA1, 3MA and the ROS scavenger NAC inhibit both autophagy and apoptosis $[85,94,97-99]$. The drug dosage, duration of treatment, and cell specificity could be responsible for the discrepancy in findings.

Table 3. List of studies from the last 10 years investigating the effect of ART-type drugs related to autophagy in cancer cells with information on the model systems used, the ART-type drugs tested and the major findings of the study.

\begin{tabular}{|c|c|c|c|}
\hline Cell Lines; Cancer & Drugs & Effects & Ref. \\
\hline K562; Leukemia & DHA & 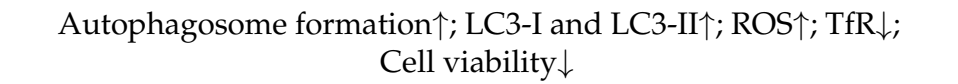 & 2012 [100] \\
\hline $\begin{array}{l}\text { Eca109, Ec9706; } \\
\text { Esophageal cancer }\end{array}$ & DHA & Autophagosome formation $\uparrow$; LC3-I and LC3-II $\uparrow$ & 2013 [59] \\
\hline Diverse cell lines & DHA & 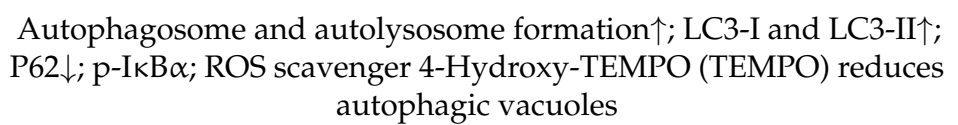 & 2014 [101] \\
\hline $\begin{array}{l}\text { BxPC-3, PANC-1; } \\
\text { Pancreatic cancer }\end{array}$ & DHA & 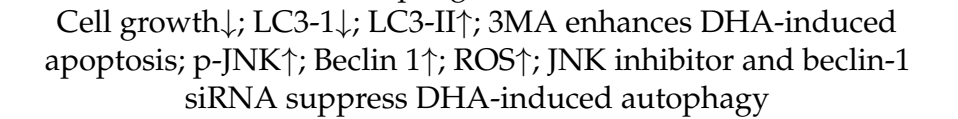 & 2014 [95] \\
\hline $\begin{array}{l}\text { Cal-27; Tongue squamous } \\
\text { cell carcinoma }\end{array}$ & DHA & 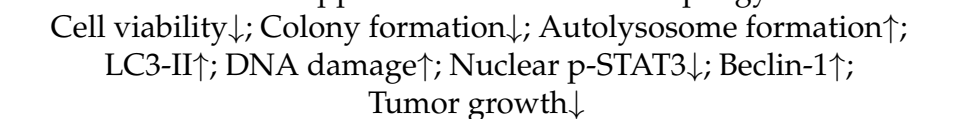 & 2017 [102] \\
\hline SKOV3; Ovarian cancer & ATS DHA & $\begin{array}{c}\text { Cell viability } \downarrow ; \text { Beclin- } 1 \uparrow ; \text { LC3-II } \uparrow \text {; Autophagosome formation } \uparrow \text {; Cell } \\
\text { viability rescued by CQ and BafA1 }\end{array}$ & 2018 [98] \\
\hline
\end{tabular}


Table 3. Cont.

\begin{tabular}{|c|c|c|c|}
\hline Cell Lines; Cancer & Drugs & Effects & Ref. \\
\hline Cholangiocarcinoma & DHA & 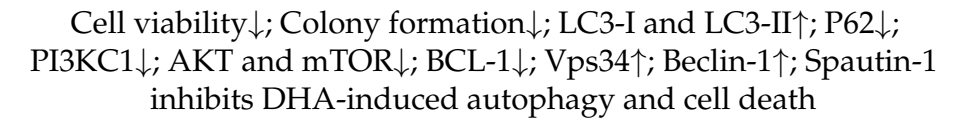 & 2018 [99] \\
\hline Diverse cell lines & DHA-37 & 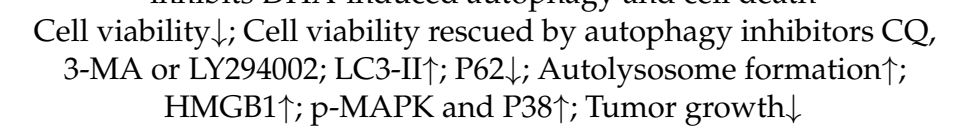 & 2018 [103] \\
\hline HCT116; Colon cancer & ATS & $\begin{array}{c}\text { Cell viability } \downarrow ; \text { Autolysosome formation } \uparrow ; \text { Atg } 5 \uparrow ; \text { Beclin- } 1 \uparrow ; \mathrm{LC} 3-\mathrm{II} \uparrow ; \\
\text { Autophagy inhibitor HCQ promotes ATS-induced apoptosis; } \\
\text { Tumor growth } \downarrow\end{array}$ & 2018 [96] \\
\hline $\begin{array}{l}\text { SU-DHL-4, SU-DHL-10, } \\
\text { OCI-LY3; Diffuse large B } \\
\text { cell lymphoma }\end{array}$ & SM1044 & $\begin{array}{c}\text { Autolysosome formation } \uparrow \text {; LC3-II } \uparrow \text {; Autophagy inhibitors CQ and } \\
\text { BafA1 inhibit DHA-induced apoptosis; p-AMPK } \uparrow \text {; ULK1 } \uparrow \text {; } \\
\text { Ceramide } \uparrow \text {; Caramide inhibitor S1P and l-cycloserine, the } \\
\mathrm{Ca}^{2+} \text { / calmodulin-dependent kinase kinases inhibitor STO-609 inhibit } \\
\text { AMPK activation; Tumor growth } \downarrow\end{array}$ & 2018 [97] \\
\hline $\begin{array}{l}\text { HepG2215; } \\
\text { Hepatocellular carcinoma }\end{array}$ & DHA & $\begin{array}{c}\text { Cell viability } \downarrow \text {; Colony formation } \downarrow ; \text { DNA damage } \uparrow \text {; Autolysosome } \\
\text { formation } \uparrow ; \text { P } 62 \downarrow ; \text { LC3-II } \uparrow ; \text { ROS } \uparrow ; \text { c cell mobility } \downarrow ;\end{array}$ & 2019 [104] \\
\hline HeLa; Cervical cancer & DHA & $\begin{array}{c}\text { Cell viability } \downarrow ; \text { Tumor growth } \downarrow ; \mathrm{LC} 3 \text { puncta } \uparrow ; \mathrm{LC} 3-\mathrm{II} \uparrow ; \text { Autolysosome } \\
\text { formation } \uparrow ; \operatorname{ROS} \uparrow ; \gamma \mathrm{H} 2 \mathrm{AX} \uparrow ; \mathrm{DNA} \text { damage } \uparrow ; \mathrm{p}-\mathrm{mTOR}\end{array}$ & 2019 [105] \\
\hline $\begin{array}{l}\text { Eca109; Esophagus squamous } \\
\text { cell carcinoma }\end{array}$ & DHA & $\begin{array}{c}\text { Cell viability } \downarrow ; \text { Tumor growth } \downarrow ; \text { ROS } \uparrow ; \text { LC3 puncta } \uparrow ; \text { P62 } \downarrow ; \text { LC3-II } \uparrow ; \\
\text { TRF2 } \downarrow ; \text { NAC reduces LC3 puncta }\end{array}$ & 2020 [106] \\
\hline Diverse cell lines & DHA & 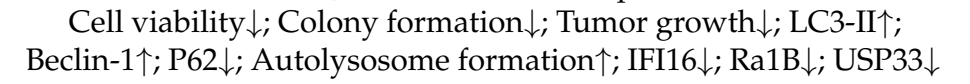 & 2020 [107] \\
\hline $\begin{array}{l}\text { TE-1, Eca109; } \\
\text { Esophageal cancer }\end{array}$ & DHA & $\begin{array}{l}\text { Cell migration } \downarrow ; \mathrm{LC} 3 \text { puncta } \uparrow ; \mathrm{LC} 3 \uparrow ; \mathrm{P} 62 / \mathrm{SQSTM} \downarrow ; 3 \mathrm{MA} \text { or } \\
\text { overexpression of Akt restores DHA-suppressed migration; } \mathrm{p}-\mathrm{AKT} \\
\text { and p-mTOR } \downarrow \text {; E-cadherin } \uparrow ; \mathrm{N} \text {-cadherin } \downarrow \text {; Vimentin } \downarrow\end{array}$ & 2020 [108] \\
\hline EJ, T24; Bladder cancer & ATS & $\begin{array}{c}\text { Cell viability } \downarrow \text {; Cell migration } \downarrow \text {; Colony formation } \downarrow \text {; Autolysosome } \\
\text { formation } \uparrow ; \text { p-AMPK and p-ULK1 } \uparrow \text {; p-mTOR } \downarrow \text {; LC } 3 \text {-II/I ratio } \uparrow ; 3 M A \\
\text { inhibits ATS-induced apoptosis; AMPK activator enhances } \\
\text { ATS-induced autophagy and apoptosis; AMPK inhibitor, 3MA, and } \\
\text { NAC suppresses ATS-induced apoptosis; ROS } \uparrow\end{array}$ & 2020 [94] \\
\hline $\begin{array}{l}\text { BON-1, QGP-1; Pancreatic } \\
\text { neuroendocrine cancer }\end{array}$ & ATS & $\begin{array}{c}\text { Cell viability } \downarrow ; \text { Cell death rescued by 3MA; LC3-II } \uparrow ; \text { DHA induces } \\
\text { apoptosis, ferroptosis, and autophagy }\end{array}$ & 2020 [109] \\
\hline $\begin{array}{l}\text { Ishikawa, AN3CA; } \\
\text { Endometrial carcinoma }\end{array}$ & ATS & $\begin{array}{l}\text { Cell viability } \downarrow ; \text { Cell migration } \downarrow ; \mathrm{CD} 155 \uparrow ; \mathrm{P} 62 \downarrow ; \text { LC3-II/I ratio } \uparrow ; \\
\text { ATG5 } \uparrow \text {; ATS-treated cancer cell triggers NK92 cytotoxicity }\end{array}$ & 2021 [110] \\
\hline $\begin{array}{l}\text { U2932, SU-DHL2, SU-DHL4, } \\
\text { SU-DHL6, } 293 \text { T; Diffuse large } \\
\text { B cell lymphoma }\end{array}$ & ATS & $\begin{array}{c}\text { Cell viability } \downarrow \text {; Colony formation } \downarrow ; \text { Apoptosis } \uparrow \text {; P62 } \downarrow ; \text { LC3-II/I ratio } \uparrow \text {; } \\
\text { Acidic vesicular organelles formation } \uparrow \text {; CQ reduces ATS-induced } \\
\text { apoptosis; p-STAT3 } \uparrow \text {; Knockdown of STAT3 enhances ATS-induced } \\
\text { autophagy, apoptosis, and ferroptosis; Tumor growth } \downarrow\end{array}$ & $2021[85]$ \\
\hline
\end{tabular}

Arrow " $\uparrow$ " indicates an enhancing effect or upregulation; “ $\downarrow$ ” indicates a diminishing effect or downregulation.

\subsection{Other Types of Regulated Cell Death}

Necroptosis and pyroptosis are forms of RCD while sharing similar morphological features compared with necrosis. Both induce plasma membrane pore formation and result in rapid lytic cell death. When cells suffer the endogenous or external blockage of the apoptosis pathway, the TNF- $\alpha$ /TNFR1, IFN/IFNR, or the LPS/TLR signaling transduction will initiate necroptosis [111,112]. Subsequently, it triggers the RIPK1 autophosphorylation and the formation of the RIPK1/RIPK3 complex (known as necrosome) [113]. RIPK3 further promotes the oligomerization and translocation of MLKL to the plasma membrane to form pores (Figure 2, yellow part IV), which releases the cellular contents, the DamageAssociated Molecular Patterns (DAMPs) and the other cytokines [114].

Button et al. found that ATS is capable of inducing RIPK1 expression and MLKL phosphorylation in RT4 schwannoma cells [115] (Table 4). However, the ATS-induced RIPK1 expression was not confirmed in the other cell lines [116,117]. Meanwhile, the RIPK1 inhibitor necrostatin-1 (Nec) partially rescues ATS-induced cell death $[78,115,116]$. The mentioned results are still insufficient to conclude, more evidence on caspase- 8 condition, RIPK1/RIPK3 phosphorylation, and morphological analysis is needed. 
Table 4. List of studies from the last 10 years investigating the effect of ART-type drugs related to necroptosis and pyroptosis in cancer cells with information on the model systems used, the ART-type drugs tested and the major findings of the study.

\begin{tabular}{|c|c|c|c|}
\hline Cell Lines; Cancer & Drugs & Effects & Ref. \\
\hline \multicolumn{4}{|l|}{ Necroptosis } \\
\hline Diverse cell lines & ATS & 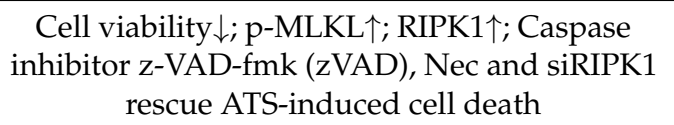 & 2014 [115] \\
\hline Diverse cell lines & ATS & $\begin{array}{c}\text { Cell viability } \downarrow ; \text { ROS } \uparrow \text {; Mitochondrial ROS } \uparrow ; \\
\text { zVAD, Nec, siRIPK1, and ROS scavengers } \\
\text { rescue ATS-induced cell death; }\end{array}$ & 2017 [116] \\
\hline $\begin{array}{l}\text { MT-2, MT-4, } \\
\text { HUT-102; Leukemia }\end{array}$ & ATS & $\begin{array}{l}\text { T-cell growth } \downarrow ; \operatorname{ROS} \uparrow ; \text { Nec rescues ATS-induced } \\
\text { cell death; Tumor growth } \downarrow\end{array}$ & 2020 [78] \\
\hline \multicolumn{4}{|l|}{ Pyroptosis } \\
\hline $\begin{array}{l}\text { MCF-7, MDA-MB-231; } \\
\text { Breast cancer }\end{array}$ & DHA & 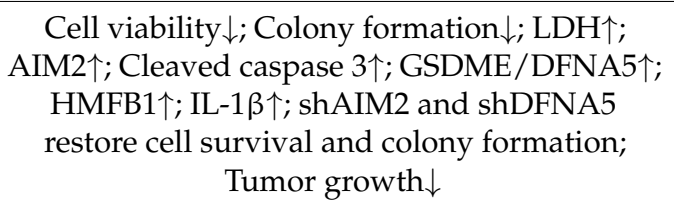 & 2021 [118] \\
\hline $\begin{array}{l}\text { Eca109, Ec9706; } \\
\text { Esophageal squamous } \\
\text { cell carcinoma }\end{array}$ & DHA & $\begin{array}{c}\text { Cell viability } \downarrow ; \text { LDH } \uparrow ; \text { IL- } 1 \beta \uparrow ; \text { GSDME-NT } \uparrow \text {; } \\
\text { Cleaved caspase } 3 \uparrow ; \text { Caspase inhibitor } \\
\text { Ac-DEVD-CHO reduces GSDME-NT, LDH, } \\
\text { IL-1 } \beta \text {, and rescue cell viability; Tumor growth } \downarrow\end{array}$ & 2021 [119] \\
\hline
\end{tabular}

Pyroptosis is caspase-dependent cell death stimulated by bacteria, virus invasion, chemotherapy drugs, or toxins $[120,121]$. It is mainly related to inflammasome activation and inflammatory response. Pyroptosis-related pattern recognition receptors (PRRs) include Toll-like receptors (TLRs), intracellular nucleotide-binding oligomerization domainlike receptors (NLRs), and AIM2-like receptors, which recruit procaspase-1 via ASC to form inflammasome [122]. Then, the active caspase- 1 cleaves gasdermin D (GSDMD) into N-terminal fragment (GSDMD-NT) to form pores on the cell membrane and result in pyroptosis [123]. It has also been shown that active caspase-3 can perform the same task [124].

It has been reported that chemotherapy drugs (doxorubicin, cisplatin) induce pyroptosis through caspase-3 dependent Gasdermin E (GSDME) activation [125]. Similarly, DHA was shown to induce caspase-3 cleavage to activate GSDME in breast and esophageal squamous cell cancers (Table 4). With the formation of the GSDME pore, higher levels of lactate dehydrogenase (LDH, cell membrane rupture indicator) and interleukin-1 $\beta$ (IL-1 $\beta$ ) were detected in treated cells. Moreover, the knockdown of AIM2 or GSDME partially restores the cell viability in DHA-treated cells [118,119]. ART-type drug-induced pyroptosis is mainly through the activation of caspase-3-induced GSDME-NT pore formation (Figure 2, pink part V). This process intersects with ART-type drug-induced apoptosis through caspase-3.

In summary, ART-type drugs induce multiple RCD pathways to execute cell death in cancer cells. Since apoptosis, ferroptosis, autophagy, pyroptosis, or necroptosis (more evidence needed) have a dynamic connection in signal transduction. ART-type drugs have diverse consequences on the cellular level (Figure 2).

\section{Combination Treatment of ART-Type Drugs with RCD-Targeting Biologics in Cancer}

Artemisinin's anti-tumor properties and mechanisms have been well established. As FDA-approved anti-malaria treatments, ART-type drugs are economically feasible and rapidly available for cancer patients. Although the application of monotherapy (single medication treatment) is still common in some cancer therapeutics, the combination treatments 
are more effective, less susceptible to drug resistance with fewer side effects [126-128]. Based on the ART-related RCD pathways, the combination of ART-type drugs with recombinant proteins or antibodies targeting the respective RCD pathways promises superior specificity and efficacy in cancer.

As a family member of the TNF superfamily, TRAIL induces the caspase-dependent extrinsic apoptosis pathway via binding with death receptors (DR4 or DR5) [129]. Recombinant TRAIL has been extensively analyzed and shown a selective anti-tumor activity in vitro and clinical trials as a tumor therapeutic [130-132]. However, some cancer cells are relatively resistant to TRAIL-induced apoptosis, because of the insufficient expression or mutation of death receptors on the cell surface, overexpression of anti-apoptotic proteins (Bcl-2, c-FLIP, XIAP), or the defects of caspases or essential molecules [133]. To stimulate tumor cells to undergo TRAIL-induced apoptosis, ART-type drugs have become prominent due to their linkage with the apoptosis pathway. ART-type drugs not only induce apoptosis themselves but also manipulate the key proteins of the apoptosis pathway in cancer cells. Therefore, the potency of combining recombinant TRAIL with ART-type drugs was investigated in a variety of cancer cells and in vivo. He et al. first carried out the exploration in human prostate cancer cells, demonstrating that DHA upregulates DR5 expression and that the combination treatment significantly promotes tumor cell death [134]. Later, Kong et al. confirmed the effectiveness of this therapy in BxPC-3 cells subcutaneously xenografted into nude mice [135]. Moreover, Ilamathi et al. observed increased DR4 expression in ART-treated hepatocellular cancer cells, in which the efficacy is enhanced under the inhibition of STAT3 [50]. Recently, our research group found that ART-type drugs increase DR5 expression in a P53-dependent manner in wild-type P53 colon cancer cells and that the combination treatment of ATS/DHA with a DR5-specific TRAIL variant remarkably increases cell death in 3D spheroids [49]. Altogether, the combination of ART-type drugs with TRAIL indicates a synergy and improved effects in cancer treatment, which shows great potential for future clinical trials.

Transferrin (TF) is a crucial glycoprotein to maintain iron homeostasis and transport iron into cells via transferrin receptor (TfR)-mediated endocytosis. As an iron-dependent cell death mechanism, ferroptosis is strongly connected with iron metabolism and dyshomeostasis, in which both TF and TfR play important roles [136,137]. Compared with untransformed cells, overexpression of TfR has been observed in cancer cells [138]. Therefore, the combination treatment of recombinant TF with ART has been established to enhance ROS generation, improve ART-induced ferroptosis, and target tumor cells [138]. In 1995, Lai and Singh first combined DHA with Holo-transferrin as a treatment, exhibiting selective cytotoxicity to lymphoblastic leukemia cells [139]. More studies were performed and showed similar effects in different cancer types [140-143]. Moreover, multiple ART-transferrin conjugates have been established, demonstrating better tumor selectivity and lower toxicity to normal tissue compared with mono-treatment [144-146]. Recently, our group revealed that holo-transferring in combination with DHA induces both apoptosis and ferroptosis in breast cancer cells [147]. Apart from TRAIL and TF, ATS was combined with Rituximab, a commercial antibody specifically targeting CD20 on the surface of B cells. The co-treatment significantly decreased the cell viability of non-Hodgkin's lymphoma cells [148].

For now, the strategy of ART-type drugs combination with biologics is focused on a few targets in the apoptosis and ferroptosis pathways. An additional example was described by Ji et al., who demonstrated that DHA also upregulates FAS expression in osteosarcoma cells [52], which provides a possibility to combine ART-type drugs with FasL fusion proteins to target cancer cells. Besides, it has been found that recombinant human arginase (rhArg) induces cancer cell apoptosis and autophagy via ROS accumulation [149-151]. It will be interesting to investigate the efficacy of the combination treatment of ART-type drugs and rhArg in inducing apoptosis and autophagy in cancer treatment. In summary, the combination of biologics with ART-type drugs shows synergistic effects in cancer treatment, yet a wider range of combinations still waits to be explored. For the thus far 
tested combination treatments, further in vivo studies and clinical trials are needed to assess their true potential in cancer treatment.

\section{Delivery of Art-Type Drugs with Nanocarriers}

The anti-tumor efficacy of ART-type drugs is limited by poor water solubility and bioavailability, short half-life, and chronic toxicity [152]. In order to enhance their therapeutic effectiveness, multiple nanocarriers have been explored for the delivery of ART-type drugs. Nanocarriers are formed by nanomaterials, aiming for the transportation of substances. Progress in ART-loaded nanocarriers has opened up massive opportunities in the recent ten years (Table 5).

Table 5. List of studies reporting the delivery of ART-type drugs with nanocarriers detailing the carrier material, cargo, model systems and main findings of the studies compared to free drugs.

\begin{tabular}{|c|c|c|c|c|}
\hline Carrier Materials & Cargo & Cell Lines; Cancer & Main Outcomes & Ref. \\
\hline \multicolumn{5}{|l|}{ Inorganic-based NPs } \\
\hline $\mathrm{MnSiO}_{3}, \mathrm{Fe}_{3} \mathrm{O}_{4}$ & ART & A549; Lung cancer & $\mathrm{Mn}^{2+}$ release $\uparrow ;$ Antitumor activity in vivo $\uparrow$ & 2015 [153] \\
\hline Fe (III) carboxylate & DHA & $\begin{array}{l}\text { HeLa; Cervical cancer. } \\
\text { A549; Lung cancer }\end{array}$ & $\begin{array}{c}\text { Co-release of DHA and } \mathrm{Fe}^{3+} \text {; Complete tumor } \\
\text { cure with no observable side effects on } \\
\text { normal tissues }\end{array}$ & 2016 [154] \\
\hline $\begin{array}{l}\text { Dual metal-organic- } \\
\text { frameworks }\end{array}$ & ART & HeLa; Cervical cancer & $\begin{array}{c}\text { High tumor inhibition rate ( 2-fold of free ART); } \\
\text { No obvious effect on the major organs of mice } \\
\text { Generation of ROS under visual light }\end{array}$ & 2016 [155] \\
\hline $\mathrm{HA}-\mathrm{TiO}_{2}$ & ART & MCF-7; Breast cancer & $\begin{array}{l}\text { irradiation; Higher concentration of ART in } \\
\text { tumor tissue }\end{array}$ & $2017[156]$ \\
\hline $\begin{array}{l}\text { Mesoporous NiO, } \\
\text { Tb-DPTA }\end{array}$ & ART & HeLa; Cervical cancer & $\begin{array}{c}\mathrm{Ni}^{2+} \text { release } \uparrow \text {; Antitumor activity in vitro and } \\
\text { in vivo } \uparrow\end{array}$ & 2018 [157] \\
\hline $\mathrm{ZnFe}_{2} \mathrm{O}_{4}$ & ART & Diverse cell lines & $\begin{array}{l}\text { Lower cell viability than free ART } \\
\text { Easv release of } \mathrm{Fe}^{2+} \text { by weak acidic etching. }\end{array}$ & 2018 [158] \\
\hline $\mathrm{SiO}_{2}, \mathrm{Fe}_{3} \mathrm{O}_{4}$ & ART & HepG-2; Liver cancer & $\begin{array}{c}\text { Easy release of } \mathrm{Fe}^{2+} \text { by weak acidic etching; } \\
\text { Enhanced production of ROS with NIR } \\
\text { light irradiation }\end{array}$ & 2019 [159] \\
\hline Mesoporous silica & $\mathrm{ART}, \mathrm{TF}$ & $\begin{array}{l}\text { MCF-7; Breast cancer. } \\
\text { CT26; Colon cancer }\end{array}$ & $\begin{array}{c}\text { Co-delivery of iron to cancer cells; Release of } \\
\text { ART in the presence of cathepsin B; ROS } \uparrow ; \\
\text { Glutathione } \downarrow \text {; Anti-cancer efficacy in vitro and } \\
\text { in vivo } \uparrow\end{array}$ & 2019 [160] \\
\hline $\begin{array}{l}\mathrm{FeCl}_{3} \cdot 6 \mathrm{H}_{2} \mathrm{O}, \mathrm{Na}_{3} \mathrm{Cit} \\
2 \mathrm{H}_{2} \mathrm{O}, \mathrm{NaOAc}\end{array}$ & DHA & $\begin{array}{l}\text { MCF-7, MDA-MB-231, } \\
\text { MDA-MB-453; } \\
\text { Breast cancer }\end{array}$ & $\begin{array}{c}\mathrm{Fe}^{2+} \text { release } \uparrow ; \text { High toxicity to intractable breast } \\
\text { cancer cells }\end{array}$ & 2020 [161] \\
\hline $\begin{array}{l}\text { Hollow mesoporous } \\
\text { manganese trioxide }\end{array}$ & ART, Mn & MCF-7; Breast cancer & Deep penetration of solid tumors & $2021[162]$ \\
\hline \multicolumn{5}{|l|}{ Liposomes } \\
\hline PPC, PEG2000 & ART & MCF-7; Breast cancer & Half $\mathrm{IC}_{50}$ compared to free ART & 2013 [163] \\
\hline P90G, CHOL & DHA & MCF-7; Breast cancer & Better cellular uptake efficiency & 2014 [164] \\
\hline DQA-PEG2000-DSPE & AM, DOX & C6; Brain cancer & $\begin{array}{c}\text { Transport of drug across BBB, elimination of } \\
\text { brain CSCs; Destruction of vasculogenic } \\
\text { mimicry channels }\end{array}$ & 2014 [165] \\
\hline DPPC, DSPC, CHOL & $\mathrm{ART}, \mathrm{TF}$ & $\begin{array}{l}\text { MCF-7, MDA-MB-231; } \\
\text { Breast cancer }\end{array}$ & $\begin{array}{l}\text { 10- and 5.5-fold higher levels of ART and TF } \\
\text { production than free drugs; Tumor volume } \\
\text { in mice } \downarrow\end{array}$ & 2015 [166] \\
\hline DPPC, mPEG2000 & $\begin{array}{l}\text { ART } \\
\text { Dimer }\end{array}$ & $\begin{array}{l}\text { MDA-MB-231; } \\
\text { Breast cancer }\end{array}$ & Better anti-tumor efficacy than Paclitaxel & 2015 [167] \\
\hline $\begin{array}{l}\text { Hollow mesoporous } \\
\text { silica, } \mathrm{Fe}_{3} \mathrm{O}_{4}\end{array}$ & ART & $\begin{array}{c}\text { ZR75-30; } \\
\text { Ductal carcinoma }\end{array}$ & $\begin{array}{l}\text { Lysosomal environment-responsively released } \\
\text { ART result in decreased cell viability }\end{array}$ & $2017[168]$ \\
\hline $\begin{array}{l}\text { EPC, CHOL, } \\
\text { PEG2000-DSPE }\end{array}$ & $\begin{array}{l}\text { DHA, } \\
\text { Epirubicin }\end{array}$ & $\begin{array}{l}\text { MDA-MB-435S, } \\
\text { MDA-MB-231, MCF-7; } \\
\text { Breast cancer }\end{array}$ & $\begin{array}{c}\text { Drug circulation } \uparrow ; \text { Targeting delivery to the } \\
\text { tumor; Anticancer efficacy } \uparrow \text { than free DHA or } \\
\text { Epitubicin }\end{array}$ & 2018 [169] \\
\hline
\end{tabular}


Table 5. Cont.

\begin{tabular}{|c|c|c|c|c|}
\hline Carrier Materials & Cargo & Cell Lines; Cancer & Main Outcomes & Ref. \\
\hline DSPE-PEG2000-NHS & $\begin{array}{l}\text { DHA, } \\
\text { Daunoru- } \\
\text { bicin }\end{array}$ & $\begin{array}{l}\text { MDA-MB-435S; Breast } \\
\text { cancer }\end{array}$ & $\begin{array}{l}\text { More accumulation in tumor than free DHA; } \\
\text { Better antitumor efficacy with no obvious } \\
\text { toxicity in mice }\end{array}$ & 2018 [170] \\
\hline $\begin{array}{l}\text { CHOL, cRGD-PEG-DSPE, } \\
\text { phospholipids, } \mathrm{Fe}_{3} \mathrm{O}_{4}\end{array}$ & $\begin{array}{l}\text { ART, } \\
\text { Cisplatin }\end{array}$ & A549/R; NSCLC & $\begin{array}{l}\text { The } 15.17 \text {-fold lower } \mathrm{IC}_{50} \text { value of free cisplatin } \\
\text { against A549/R cells, ROS } \uparrow \text {; Cell apoptosis rates } \uparrow\end{array}$ & 2018 [171] \\
\hline $\begin{array}{l}\mathrm{FeCl}_{3} \cdot 6 \mathrm{H}_{2} \mathrm{O}, \mathrm{FeSO}_{4} \cdot 7 \mathrm{H}_{2} \mathrm{O} \\
\text { sodium oleate, sodium } \\
\text { hydroxide, Acetonitrile. }\end{array}$ & DHA & $\begin{array}{l}\text { HNSCC; Head and } \\
\text { neck squamous } \\
\text { cell carcinoma }\end{array}$ & $\begin{array}{c}\text { Significant targeting effect in a magnetic field; } \\
\text { Better inhibition of HNSCC in mice than } \\
\text { free DHA }\end{array}$ & 2019 [172] \\
\hline $\begin{array}{l}\text { Cholesteryl oleate, } \\
\text { glyceryl trioleate, } \\
\text { CHOL, DOPE }\end{array}$ & DHA, SRF & HepG2; Liver cancer & $\begin{array}{l}\text { BAX and Bcl-2个; Exhibited a 3-fold higher } \\
\text { SubG1\% of cells than free DHA or SRF }\end{array}$ & 2019 [173] \\
\hline $\begin{array}{l}\text { EPC, CHOL, } \\
\text { DSPE-PEG2000, } \\
\text { DSPE-PEG2000-R8 }\end{array}$ & $\begin{array}{l}\text { DHA, } \\
\text { Epirubicin }\end{array}$ & A549; NSCLC: & $\begin{array}{l}\text { Increased drug accumulation; Enhanced } \\
\text { specificity and anti-tumor efficacy in vivo }\end{array}$ & 2019 [174] \\
\hline $\begin{array}{l}\text { DSPE-PEG2000, } \\
\text { DOPE, CHEMS }\end{array}$ & DHA, TF & HepG2; Liver cancer & $\begin{array}{l}\text { High oxidative state at the tumor site; } \\
\text { Eradication of HepG2 tumor in mice }\end{array}$ & 2020 [175] \\
\hline DSPE-PEG2000-HE-R6 & ART & $4 \mathrm{~T} 1$; Breast cancer & $\begin{array}{l}\text { Longer retention time in tumors and higher } \\
\text { efficiency in tumor suppression }\end{array}$ & $2021[176]$ \\
\hline \multicolumn{5}{|l|}{ Micelles } \\
\hline PEG-PCL & ART & $\begin{array}{l}\text { MDA-MB-435S; } \\
\text { Breast cancer }\end{array}$ & $\begin{array}{l}\text { Specific delivery of ART to tumor site; Higher } \\
\text { antitumor efficacy than other ART formulations } \\
\text { in vivo with low toxicity }\end{array}$ & 2012 [177] \\
\hline PCL-PEG-PCL & ART & $\begin{array}{l}\text { MCF-7, 4T1; } \\
\text { Breast cancer }\end{array}$ & Prolong in vivo residence time in rats & 2018 [178] \\
\hline Biotin-PEG-PCL & ART & MCF-7; Breast cancer & $\begin{array}{c}\text { Tumor inhibition; No toxic effects on HFF2 } \\
\text { fibroblast cells }\end{array}$ & 2019 [179] \\
\hline \multicolumn{5}{|l|}{ Polymer-based NPs } \\
\hline mPEG & ATS & $\begin{array}{l}\text { L1210; Leukemia. } \\
\text { MCF7; Breast cancer }\end{array}$ & $\begin{array}{c}\text { Controllable release of ATS in the presence } \\
\text { of esterase }\end{array}$ & 2014 [180] \\
\hline $\begin{array}{l}\text { Formulation I: Gelatin; } \\
\text { Formulation II: } \\
\text { Hyaluronan }\end{array}$ & DHA & A549; NSCLC & $\begin{array}{l}\text { Formation of DHA nanosized aggregates in an } \\
\text { electrostatic field; Higher anticancer } \\
\text { proliferation activities than DHA alone in } \\
\text { A549 cells. }\end{array}$ & 2014 [181] \\
\hline $\begin{array}{l}\text { Poly(lactic-co-glycolic acid) } \\
\text { and 1,2-dipalmitoyl-sn- } \\
\text { glycero-3-phosphocholine }\end{array}$ & $\begin{array}{l}\text { DHA, } \\
\text { DOX }\end{array}$ & $\begin{array}{l}\text { HeLa; Cervical cancer. } \\
\text { HepG2; Liver cancer }\end{array}$ & $\begin{array}{l}\text { Increased doxorubicin accumulation in cell } \\
\text { nuclei; cytotoxicity } \uparrow\end{array}$ & 2015 [182] \\
\hline 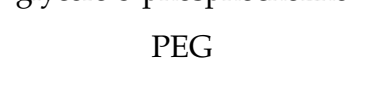 & $\begin{array}{c}\text { DHA, } \\
\text { Paclitaxel }\end{array}$ & HT-29; Colon cancer & $\begin{array}{l}\text { Higher accumulation in the tumor site; Tumor } \\
\text { growth in vivo } \downarrow \text {; Systemic toxicity } \downarrow\end{array}$ & 2015 [183] \\
\hline Graphene oxide & DHA, TF & EMT6; Breast cancer & $\begin{array}{l}\text { Significant enhancement of delivery specificity } \\
\text { and tumor cytotoxicity; Complete tumor cure } \\
\text { in mice }\end{array}$ & 2015 [184] \\
\hline PEG & DHA, TF & LLC; Lung cancer & $\begin{array}{c}\text { High solubility ( 102-fold of free DHA); } \\
\text { Relatively high drug loading; Circulating } \\
\text { half-life } \uparrow ; \text { One-fifth the size of the tumor in } \\
\text { free DHA }\end{array}$ & 2016 [185] \\
\hline H-apoferritin & AS & Hela; Cervical cancer & $\begin{array}{l}\text { pH-responsive release of AS; Cytotoxic ROS } \uparrow ; \\
\text { Cytotoxicity } \uparrow ; \text { Biocompatibility } \uparrow ; \text { No additional } \\
\text { side effects }\end{array}$ & 2019 [186] \\
\hline $\mathrm{PNE}, \mathrm{FeOOH}$ & ART & $\begin{array}{l}\text { 4T1; Mouse } \\
\text { breast cancer }\end{array}$ & $\begin{array}{l}\text { Extremely low toxicity to normal tissue; Tumor } \\
\text { elimination after 7-day treatment; No tumor } \\
\text { recurrence in } 30 \text { days after treatment. }\end{array}$ & 2019 [187] \\
\hline $\begin{array}{l}\text { Iron coordinated hollow } \\
\text { polydopamine nanospheres }\end{array}$ & DHA & HeLa; Cervical cancer & 3.05-fold higher anti-tumor efficacy than free DHA & 2019 [188] \\
\hline
\end{tabular}


Table 5. Cont.

\begin{tabular}{|c|c|c|c|c|}
\hline Carrier Materials & Cargo & Cell Lines; Cancer & Main Outcomes & Ref. \\
\hline PEOz-PLA-PBAE & ATS dimer & CT-26; Colon cancer & $\begin{array}{l}\text { Enhanced cellular uptake of the drug depot by } \\
\text { the cancer cells; Enhanced anti-tumor efficacy } \\
\text { in vivo }\end{array}$ & 2020 [189] \\
\hline Bis-MPA, PEG & ART & $\begin{array}{l}\text { MCF-7, MDA-231; } \\
\text { Breast cancer }\end{array}$ & $\begin{array}{c}\text { Completely non-toxic towards } \\
\text { healthy fibroblasts }\end{array}$ & $2021[190]$ \\
\hline \multicolumn{5}{|l|}{ Carbon-based NPs } \\
\hline HA-C60 & AS & MCF-7; Breast cancer & $\begin{array}{l}\text { Increased intracellular accumulation of AS in } \\
\text { tumor; Remarkably enhanced antitumor efficacy }\end{array}$ & 2015 [191] \\
\hline \multicolumn{5}{|l|}{ NLCs } \\
\hline $\begin{array}{l}\text { Cholesterol, oleic } \\
\text { acid, stearylamine }\end{array}$ & ART & $\begin{array}{c}\text { U87MG; } \\
\text { Malignant gliomas }\end{array}$ & $\begin{array}{l}\text { High entrapment efficiency; Controlled drug } \\
\text { release for brain administration }\end{array}$ & 2018 [192] \\
\hline \multicolumn{5}{|l|}{ Niosomes } \\
\hline $\begin{array}{l}\text { Span 60, Tween 60, } \\
\text { PEG-600 }\end{array}$ & ART & MCF-7; Breast cancer & 4-fold higher cytotoxic activity than free ART & 2014 [193] \\
\hline Span 60, CHOL & Artemisone & A-375; Melanoma & $\begin{array}{l}\text { Highly selective cytotoxicity towards } \\
\text { melanoma cells, not to normal skin cells }\end{array}$ & 2015 [194] \\
\hline Span, Tween, CHOL & $\begin{array}{c}\text { AM, } \\
\text { Paclitaxel }\end{array}$ & $\begin{array}{l}\text { 4T1; Mouse } \\
\text { breast cancer }\end{array}$ & $\begin{array}{c}\text { Superior tumor necrosis and smaller tumor } \\
\text { volume than free AM }\end{array}$ & 2020 [195] \\
\hline
\end{tabular}

Here, we summarize the use of spherical ART-type drug-loaded nanocarriers, which are up to several hundred nanometers in size. Due to their physicochemical and biological properties, they have the potential to be taken up more easily by cells, including the transportation across the blood-brain barrier (BBB) [196,197]. The tumor environment is more acidic than the normal cell environment, due to the altered cell metabolism, hypoxia and deficient blood perfusion [198]. According to this feature, $\mathrm{pH}$-responsive nanoparticles have been developed enabling the specific release of encapsulated drugs in tumor tissues [175]. Moreover, nanocarriers can facilitate the co-delivery of multiple therapeutics (small molecules and biologics) and cofactors, such as ions. This improves tumor targeting and anti-tumor efficacy, and reduces the occurrence of drug resistance compared to monotherapy [199].

For ART-type drugs, several $\mathrm{pH}$-sensitive nanoparticles and co-delivery systems have been developed and tested $[162,167,200]$. The latter often rely on the fact that ART-type drugs are radical precursors which are activated by metal ions such as $\mathrm{Fe}^{2+}, \mathrm{Mn}^{2+}$, and $\mathrm{Ni}^{2+}$ through cleavage of the endoperoxide bridge by a Fenton-like reaction. Meanwhile, co-delivery systems with RCD-targeting biologics and small molecules have been explored.

In this section, we discuss different formulations of nanocarriers loaded with ART-type drugs. Information is grouped by nanocarrier material (inorganic-based nanoparticles, liposomes, polymer-based nanoparticles, carbon-based nanoparticles, and other types of nanocarriers) [197].

\subsection{Inorganic ART-Loaded Nanoparticles}

Inorganic-based nanoparticles are typically composed of inorganic compounds, such as alumina, silica, metals, and metal oxides. Compared to organic materials, they are non-toxic, hydrophilic, biocompatible and highly stable [162]. The size, shape and porosity of the nanoparticles are determined by the selected compounds used in the inorganic-based synthesis [201,202].

\subsubsection{Ion-Containing Inorganic ART-Loaded Nanoparticles}

The unique magnetic properties of ion-containing inorganic nanoparticles make them highly efficient for imaging and diagnosis in cancer therapy [162]. Moreover, since ART- 
type drugs are considered radical precursors, ion-containing inorganic nanoparticles have attracted great attention for cancer nanotherapy [203]. Zhang et al. developed visible light-sensitive iron oxide nanoparticles (IONPs): Hyaluronic Acid (HA)- $\mathrm{TiO}_{2}-\mathrm{IONPs} / \mathrm{ART}$ ( $\sim 40 \mathrm{~nm}$ size), which realized the co-delivery of ART and $\mathrm{Fe}^{2+}$. The in vitro data showed $\mathrm{HA}-\mathrm{TiO}_{2}$-IONPs generates ROS upon irradiation with visual light, resulting in apoptosis in breast cancer cell line MCF-7. Meanwhile, tumor-bearing BALB/c mice treated with $\mathrm{HA}-\mathrm{TiO}_{2}-\mathrm{IONPs}$ did not show apparent body weight loss, which demonstrated promising safety profiles. Moreover, the plasma half-life of $\mathrm{HA}-\mathrm{TiO}_{2}-\mathrm{IONPs}$ is 2.85-fold higher than that of ART [156]. ART derivatives also showed promising efficacy when capsulated into metal ion-based inorganic nanoparticles [154,161].

Other metal oxides are also employed as nanoparticle materials. ART-loaded pHresponsive mesoporous $\mathrm{NiO}(\mathrm{mNiO}-\mathrm{Tb}-\mathrm{ART})$ nanoparticles were engineered to release $\mathrm{Ni}^{2+}$ at acidic $\mathrm{pH}$, which reacts with the endoperoxide bridge in ART to produce radicals [204]. Chen et al. developed $\mathrm{Fe}_{3} \mathrm{O}_{4} @ \mathrm{MnSiO}_{3}-\mathrm{FA}$ which supplies $\mathrm{Mn}^{2+}$ and ART to the tumor in A549 xenograft mouse models. According to cell viability assays, they demonstrated that $\mathrm{Mn}^{2+}$ is more effective in catalyzing the Fenton-like reaction than $\mathrm{Fe}^{2+}$. This was the first report to demonstrate that $\mathrm{Mn}^{2+}$ assists ART to achieve higher anticancer efficiency [153]. Nanoparticles constituted by hollow mesoporous manganese trioxide $\left(\mathrm{Mn}_{2} \mathrm{O}_{3}\right)$ and ART (TKD@RBCm- $\mathrm{Mn}_{2} \mathrm{O}_{3}-\mathrm{ART}$ ) were shown to have a drug release percentage of $97.5 \%$. Furthermore, the release of $\mathrm{Mn}_{2} \mathrm{O}_{3}$ in mice enhanced the magnetic resonance imaging (MRI) capability and can be used for the diagnosis of breast cancer. [162]. $\mathrm{Zn}^{2+}-\mathrm{Fe}^{2+}$ co-released $\left(\mathrm{ZnFe}_{2} \mathrm{O}_{4}\right)$ NPs showed promising bio-imaging capacity and anti-proliferative effect in HeLa, A375 and HepG-2 cell lines [158].

\subsubsection{Other Inorganic ART-Loaded Nanoparticles}

Other inorganic-based nanoparticle studies also improved the anti-cancer effects. Due to the combination of silicon hydrophilic features with promising stability, Luo et al. developed mesoporous silica nanoparticles co-loaded with ART, buthionine-sulfoximine, and transferrin peptide. TF peptide guides the nanoparticle to TfR overexpressing malignant tumor cells and cathepsin B control the release of ART and buthionine-sulfoximine to increase ROS production, decrease GSH levels and thus induce tumor cell death [160]. In another design, dual-metal-organic-frameworks (MOFs)@ART release ART due to the $\mathrm{pH}$-responsive degradation of outer MOFs in an acidic tumor environment. Strong absorbance in the near-infrared region by inner MOFs makes the combination treatment of chemo-photothermal therapy promising. Furthermore, dual MOFs improved imaging by MRI and fluorescence optical imaging (FOI) [155].

\subsection{ART-Type Drug-Loaded Liposomes}

Liposomes, the first developed drug carriers, are simple sphere-shaped vesicles with a diameter of 80-300 nm, consisting of one or more phospholipid bilayers. As they are directly taken up by cells through endocytosis or fusion with cell membranes, they can enhance the absorption of the encapsulated drugs [196,205-207]. The encapsulation by liposomes also helps to increase the stability and reduce the toxicity of the agent. They are non-toxic, biocompatible, completely biodegradable, and non-immunogenic. However, they are limited by low solubility, unexpected leakage of encapsulated drugs, and high production costs [205].

Single ART and ART derivatives loaded in liposomes were shown to have anti-tumor efficacy $[164,172]$. Building on that, $\mathrm{pH}$-responsive release mechanisms were explored to increase the accumulation of ART-type drugs specifically at tumor sites, thereby reducing side effects $[163,167,176]$. For example, Dadgar et al. combined ART, phosphatidylcholine and polyethylene glycol 2000 together into a liposomal formulation, in which polyethylene glycol increases the solubility and the encapsulation of ART. This nanoliposomal formulation showed better cytotoxic ability than standard ART in the MCF-7 cell line [163]. 
Furthermore, co-delivery of ART-type drugs with cisplatin resulted in greatly enhanced anti-cancer effects to A549 cells in vitro. And in vivo, co-delivery of ART-type drugs with sorafenib, epirubicin, or daunorubicin was demonstrated to have synergistic anti-cancer effects in liver tumors, non-small cell lung cancer (NSCLC), and breast cancer $[169-171,173,174]$. Invasive brain glioma was efficiently treated by co-delivery of paclitaxel and artemether in mannose-vitamin E derivative conjugate (MAN-TPGS1000) and DQA-PEG2000-DSPE liposomes since these liposomes can easily penetrate the BBB [165]. The co-delivery of TF and ART-type drugs in liposomes also resulted in targeted drug delivery and enhanced therapeutic efficacy in liver and breast tumor-bearing mouse models $[166,175]$.

Lastly, metal ions were also applied in liposomes. Fu et al. loaded ART into the inner space of hollow mesoporous silica (HMS) liposomes, with $\mathrm{Fe}_{3} \mathrm{O}_{4}$ immobilized on the surface. ART@HMS- $\mathrm{Fe}_{3} \mathrm{O}_{4}$ is taken up into lysosomes and in the acidic lysosomal environment, $\mathrm{Fe}^{2+}$ is released to activate ART, which leads to cytotoxicity in ductal carcinoma ZR75-30 cell line [168].

\subsection{Polymer-Based ART-Loaded Nanoparticles}

Polymeric nanoparticles can be defined as solid particles made up of polymers with a size range of 1-100 $\mathrm{nm}$. Not only chemicals but also protein or DNA material can be carried by polymeric nanoparticles [208]. They are widely used because of the high loading capacity, easy preparation technique, controllable and uniform size distribution, and longer clearance time, which is advantageous in delivering the drugs to a particular site at a particular rate [208].

An in vitro study indicated that using a dendritic-linear-dendritic hybrid copolymer based on hyperbranched 2,2-bis (hydroxymethyl) propionic acid (bis-MPA) and linear PEG chains to deliver ART-type drugs leads to anticancer biological effects on breast cancer cell lines MCF-7 and MDA-MB-231 [190]. Furthermore, GEL/DHA and hyaluronan /DHA nanoparticles inhibited the proliferation of NSCLC A549 cells [181]. Moreover, an in vivo study showed that ATS-loaded M-HFn nanoparticles accumulate on the tumor tissue and efficiently inhibit tumor growth in 4T1-bearing mice [186]. Most importantly, several codelivery systems based on polymeric nanoparticles were established: first, co-delivery of ART-type drugs and doxorubicin (DOX) or paclitaxel were demonstrated with superior results compared to free ARTs, which could be explained by the enhanced permeability and the retention effect [182,183]. Second, co-delivery of ART-type drugs with TF enhanced their tumor inhibition ability. For example, the pH-responsive DHA-GO-TF and TF-8arm-PEGDHA delivery systems both showed higher solubility, enhanced tumor delivery specificity, minimal side-effects, and superior tumor growth restrained ability in vivo $[184,185]$. Third, the release of metal ions by polymer-based nanoparticles was shown to enhance ART or ART derivative-induced tumor inhibition [187-189].

\subsection{Carbon-Based ART-Loaded Nanoparticles}

The discovery of fullerene (C60), carbon nanotube, and graphene introduce carbon nanomaterials to become hotspots as novel nanostructures. Since its discovery, C60 has attracted increasing interest in practical applications, and the biological activity, including antiviral, antioxidant, and chemotactic activities were tested. Moreover, $\mathrm{C} 60$ could generate cytotoxic ROS under laser exposure [209]. Due to these unique physicochemical properties, fullerene and graphene oxide were employed to load ART derivatives in nanoparticle delivery systems. The porous structure of carbon nanoparticles provides a large surface area, resulting in plentiful exposed modifiable sites [210]. The surface modification, such as the binding of functional groups or molecules, increases the feasibility of biological application [211]. For example, with the modification of HA, HA-fullerene (C60) showed water-soluble properties with improved dispersion ability in physiological environments than C60. C60 lacks electrons, making it a good electron acceptor to interact with TF. So, 
the co-delivery system HA-C60-Tf/ATS was designed with excellent biocompatibility and enhanced antitumor efficacy in S180 tumor mouse models [191].

\subsection{Other Types of ART-Type Drugs-Loaded Nanocarriers}

Liposomes are widely used due to their biodegradable and non-toxic properties. However, the unexpected leakage and uncontrolled fast release of liposomes also limited their applications. Thus, solid lipid nanoparticles (SLN) have been made with solid lipids to protect loaded drugs from harsh environments and achieve sustained drug release [212-214]. However, the solubility of most drugs in solid lipids is not that high, which restrained the loading capacity of SLNs. Therefore, the nanostructured lipid carriers (NLCs) were designed to incorporate liquid lipid into the solid matrix. Compared with SLNs, NLCs have higher loading capacity, slower polymorphic transition, and low crystallinity index [212]. The TF-ART-NLCs were made by Compritol ${ }^{\circledR}$, Tween 80 , oleic acid, and dichloromethane, and their cytotoxicity to the U87MG cell line was far greater than free ART [192].

Micelles are composed of lipid monolayers, where hydrophobic and hydrophilic components assemble into nano-sized spheres. They have a normal size ranging from 5 to $100 \mathrm{~nm}$, depending on the types of the hydrophilic components and length of hydrophobic chains. Micelles have the ability to increase drug solubility, reduce toxicity, and prolong circulation time making them a suitable model for drug delivery systems [215]. ART was encapsulated inside of poly (E-caprolactone)-poly (ethylene glycol)-poly (E-caprolactone) (PCL-PEG-PCL) micelles, biotin-PEG-PCL micelles, or lymphatics-homing peptide (LyP-1) conjugated PEG-PCL micelles. They all significantly increased the drug accumulation in tumors, leading to a better tumor growth inhibition capacity than free ART [177-179].

Niosomes share a similar structure with liposomes, but liposomes are made up of phospholipids with two hydrophobic tails, while niosomes are non-ionic surfactant vesicles with a single hydrophobic tail. Similar to micelles, niosomes are able to capture both hydrophilic and hydrophobic drug molecules, while being more stable than liposomes. Therefore, several ART-type drugs were encapsulated with the niosome technique [194,205]. Asgharkhani et al. prepared the ART-loaded niosomes by a certain ratio of Span-60:Tween60:PEG-600:ART, showing better inhibitory effects to MCF-7 cell line (one-fourth IC 50 compared to free ART) [193]. Compared to free artemether, artemether-loaded nanoniosomes induced more tumor necrosis and inhibited tumor growth in a 4T1-bearing mouse model [195]. Artemisone, a 10-amino-artemisinin derivative of ART, was packed into niosomes to test the inhibitory effects on the melanoma A-375 cell line. In vitro data showed that the niosome formulation of artemisone displayed high cytotoxicity to melanoma cells but no toxicity to normal skin cells. This study also packed artemisone into lipid-based nanoparticles, which showed similar results [194].

Multiple nanotechnologies have been applied to ART-type drugs and have shown different therapeutic efficacy. In general, compared with free ART-type drugs, these nanocarriers have improved bioavailability and stability. The different drug release mechanisms and co-delivery systems help to reduce side effects and improve their anti-tumor effect. In recent years, ion-containing inorganic ART-loaded nanoparticles have attracted increasing attention. Although these ART-type drug-based nanotechnologies show promising anti-tumor efficacy in vivo, the clinical data is not abundant. Further evaluation is needed.

\section{Summary}

ART-type drugs were developed to treat malaria patients and became one of the most effective drugs ever since. However, their anti-tumor activity has also attracted extensive attention due to their promising therapeutic effects in vivo and in vitro. This review systematically summarized the effect of ART-type drugs on RCD pathways and discussed the approaches to enhance their efficacy. The combination treatment with biologics, and the nanoparticles delivery methods improve the lethality and specificity of ART-type drugs for tumor cells. Despite the promising results thus far, it is important to also investigate new targets for the combination treatment based on the known RCD pathways. Furthermore, 
for now, all studies were performed on cultured cells or animal models. The lack of clinical trials makes the curative effect unpredictable and more in-depth studies are necessary.

Author Contributions: Conceptualization, X.Z. and F.S.; writing-original draft preparation, X.Z. and F.S.; writing - review and editing, K.H. and W.J.Q.; visualization, X.Z.; supervision, K.H. and W.J.Q.; funding acquisition, W.J.Q. All authors have read and agreed to the published version of the manuscript.

Funding: X.Z and F.S. received funding from China Scholarship Council (201907040076, 201708610140).

Institutional Review Board Statement: Not applicable.

Informed Consent Statement: Not applicable.

Data Availability Statement: Not applicable.

Conflicts of Interest: The authors declare no conflict of interest.

\section{Abbreviations}

$\begin{array}{ll}\text { Abb. } & \text { Full Name } \\ \text { AIM2 } & \text { Interferon-inducible protein } \\ \text { AMP } & \text { Adenosine monophosphate } \\ \text { Apaf-1 } & \text { Apoptotic protease activating factor 1 } \\ \text { ASC } & \text { Apoptosis-associated speck-like protein containing a CARD } \\ \text { ATF } & \text { Activating transcription factor } \\ \text { Atg5 } & \text { Autophagy related 5 protein } \\ \text { BafA1 } & \text { Bafilomycin A1 } \\ \text { Bax } & \text { Bcl-2-like protein 4 } \\ \text { BCE } & \text { Before common era } \\ \text { Bcl-2 } & \text { B-cell lymphoma 2 } \\ \text { Bcl-xL } & \text { B-cell lymphoma-extra large } \\ \text { Bid } & \text { BH3 interacting-domain death agonist } \\ \text { Bim } & \text { Bcl-2-like protein 11 } \\ \text { bis-MPA } & \text { 2,2-bis(hydroxymethyl)propionic acid } \\ \text { CD107a } & \text { Lysosomal-associated membrane protein-1 } \\ \text { CD155 } & \text { Cluster of differentiation 155 } \\ \text { CD20 } & \text { B-lymphocyte antigen CD20 } \\ \text { CD4 } & \text { Cluster of differentiation 4 } \\ \text { CDC25B } & \text { Cell Division Cycle 25B } \\ \text { CDK2 } & \text { Cyclin Dependent Kinase 2 } \\ \text { CDK4 } & \text { Cyclin Dependent Kinase 4 } \\ \text { CE } & \text { Common Era } \\ \text { CHAC1 } & \text { ChaC Glutathione Specific Gamma-Glutamylcyclotransferase 1 } \\ \text { CHEMS } & \text { Cholesteryl Hemisuccinate } \\ \text { CHOL } & \text { Cholesterol } \\ \text { CHOP } & \text { DNA damage-inducible transcript 3 } \\ \text { CQ } & \text { Chloroquine } \\ \text { DFNA5 } & \text { Non-syndromic hearing impairment protein 5 } \\ \text { DFO } & \text { Deferoxamine } \\ \text { DOPE } & \text { 1,2-dioleoyl- snglycero-3-phosphoethanolamine } \\ \text { DOX } & \text { Doxorubicin } \\ \text { DPPC } & \text { 1,2-dipalmitoyl-snglycero-3-phosphocholine } \\ \text { DPTA } & \text { Diethylene Triamine Pentacetate Acid } \\ \text { DQA } & \text { Dequalinium } \\ \text { DR3 } & \text { Death receptor 3 } \\ \text { DR4 } & \text { Death receptor 4 } \\ \text { DR5 } & \\ \text { DSPC } & \text { Distearoyl Phosphatidylcholine } \\ \text { DSPE } & \end{array}$




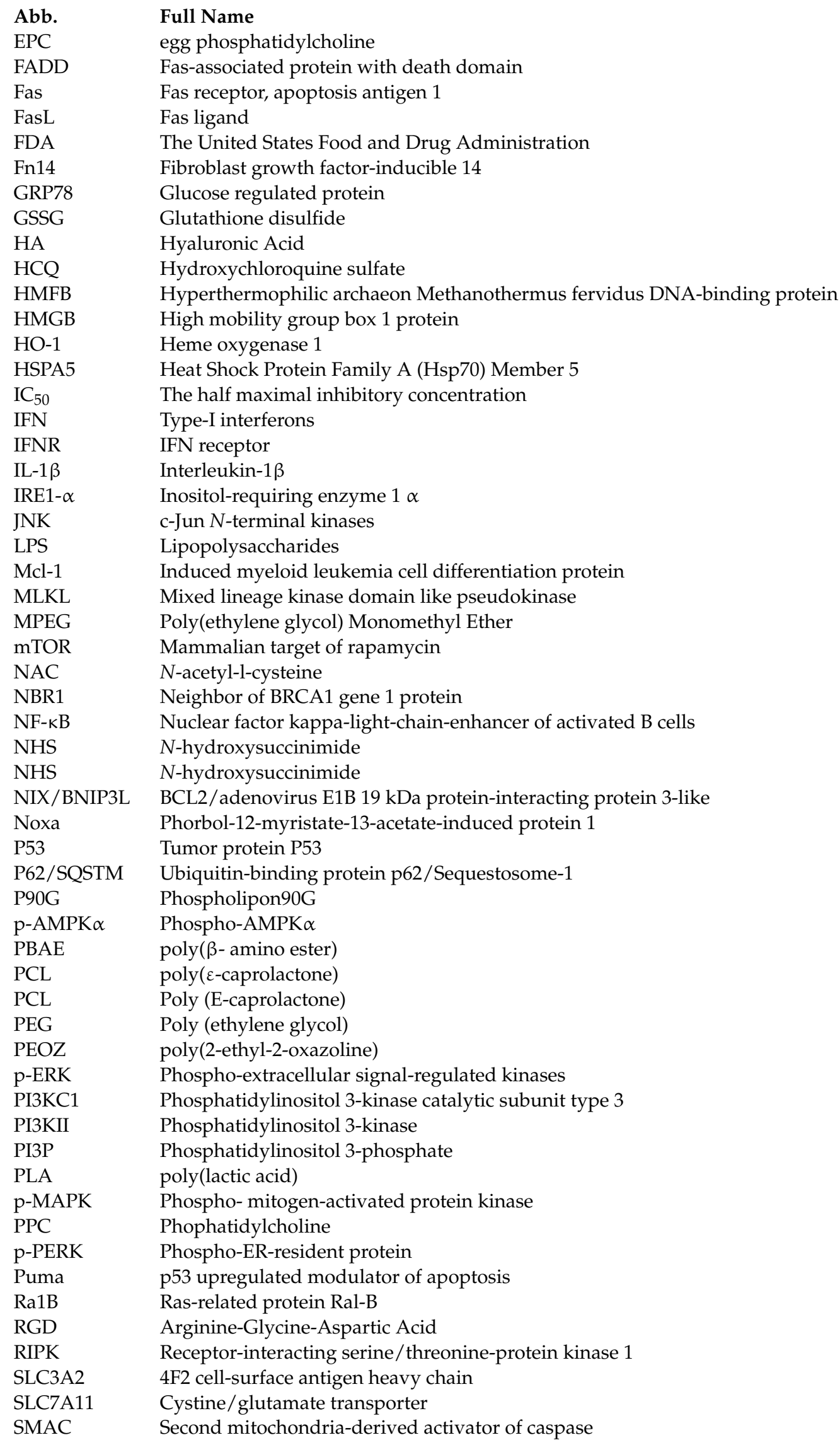




$\begin{array}{ll}\text { Abb. } & \text { Full Name } \\ \text { Sp1 } & \text { Specificity protein 1 } \\ \text { SRF } & \text { Sorafenib } \\ \text { STAT3 } & \text { Signal transducer and activator of transcription 3 } \\ \text { Surf1 } & \text { Surfeit locus protein 1 } \\ \text { Tb } & \text { Terbium } \\ \text { TEMPO } & \text { (2,2,6,6-Tetramethylpiperidin-1-yl)oxyl } \\ \text { TGF- } \beta & \text { Transforming growth factor beta } \\ \text { TLR } & \text { Toll-like receptors } \\ \text { TNFR1 } & \text { Tumor necrosis factor receptor 1 } \\ \text { TNF- } \alpha & \text { Tumor necrosis factor } \alpha \\ \text { TRADD } & \text { Tumor necrosis factor receptor type 1-associated DEATH domain protein } \\ \text { TRAIL } & \text { TNF-related apoptosis-inducing ligand } \\ \text { TRF2 } & \text { Telomeric repeat binding factor 2 } \\ \text { TWEAK } & \text { TNF-related weak inducer of apoptosis } \\ \text { ULK } & \text { Unc-51 Like Autophagy Activating Kinase 1 } \\ \text { USP33 } & \text { Ubiquitin carboxyl-terminal hydrolase 33 } \\ \text { VEGI } & \text { Vascular endothelial growth inhibitor } \\ \text { Vps34 } & \text { Class III PI 3-kinase } \\ \text { XIAP } & \text { X-linked inhibitor of apoptosis protein } \\ \text { zVAD } & \text { Caspase inhibitor z-VAD-fmk } \\ \gamma H 2 A X & \text { H2A histone family member X }\end{array}$

\section{References}

1. Muhammad, I.; Samoylenko, V. Antimalarial quassinoids: Past, present and future. Expert Opin. Drug Discov. 2007, 2, 1065-1084. [CrossRef] [PubMed]

2. Xu, C.; Zhang, H.; Mu, L.; Yang, X. Artemisinins as Anticancer Drugs: Novel Therapeutic Approaches, Molecular Mechanisms, and Clinical Trials. Front. Pharmacol. 2020, 11, 529881. [CrossRef] [PubMed]

3. Raphals, L.A. Early Chinese Medical Literature: The Mawangdui Medical Manuscripts (review). China Rev. Int. $2000,7,463-466$. [CrossRef]

4. Maude, R.J.; Woodrow, C.J.; White, L.J. Artemisinin Antimalarials: Preserving the “Magic Bullet”. Drug Dev. Res. 2010, 71, 12-19. [CrossRef]

5. Efferth, T. From ancient herb to modern drug: Artemisia annua and artemisinin for cancer therapy. Semin. Cancer Biol. 2017, 46, 65-83. [CrossRef] [PubMed]

6. Tu, Y. Artemisinin-A Gift from Traditional Chinese Medicine to the World (Nobel Lecture). Angew. Chem.-Int. Ed. 2016, 55, 10210-10226. [CrossRef]

7. Czechowski, T.; Weathers, P.J.; Brodelius, P.E.; Brown, G.D.; Graham, I.A. Editorial: Artemisinin-From Traditional Chinese Medicine to Artemisinin Combination Therapies; Four Decades of Research on the Biochemistry, Physiology, and Breeding of Artemisia annua. Front. Plant Sci. 2020, 11, 1478. [CrossRef] [PubMed]

8. Niu, Y. Artemisinin (Qing Hao Su). In Thirty Great Inventions of China; Springer: Singapore, 2020; pp. 815-845.

9. Li, Y.; Yu, P.L.; Chen, Y.X.; Li, L.Q.; Gai, Y.Z.; Wang, D.S.; Zheng, Y.P. Studies on analogs of artemisinine. I. The synthesis of ethers, carboxylic esters and carbonates of dihydroartemisinine (author's transl). Acta Pharm. Sin. 1981, 16, 429-439.

10. Zhang, R.B.; Xu, S.L.; Li, Y. Separation of artemisinine and its derivatives by reversed phase high performance liquid chromatography (author's transl). Acta Pharm. Sin. 1981, 16, 460-465.

11. Choudhary, A.; Sinha, M.; Devi, A.; Jindal, S.; Goyal, K. A Review on Antimalarial 1,2,4-Trioxane Derivatives. J. Drug Deliv. Ther. 2020, 10, 240-253. [CrossRef]

12. Rudrapal, M.; Chetia, D. Endoperoxide antimalarials: Development, structural diversity and pharmacodynamic aspects with reference to 1,2,4-trioxane-based structural scaffold. Drug Des. Devel. Ther. 2016, 10, 3575-3590. [CrossRef]

13. Patel, O.P.S.; Beteck, R.M.; Legoabe, L.J. Exploration of artemisinin derivatives and synthetic peroxides in antimalarial drug discovery research. Eur. J. Med. Chem. 2021, 213, 113193. [PubMed]

14. Grazzia, N.; Boaventura, S.; Garcia, V.L.; Gadelha, F.R.; Miguel, D.C. Dihydroartemisinin, an active metabolite of artemisinin, interferes with Leishmania braziliensis mitochondrial bioenergetics and survival. Parasitol. Res. 2021, 120, 705-713. [CrossRef] [PubMed]

15. Chen, C. Development of antimalarial drugs and their application in China: A historical review. Infect. Dis. Poverty 2014, 3, 9. [CrossRef] [PubMed]

16. Vil', V.A.; Yaremenko, I.A.; Ilovaisky, A.I.; Terent'ev, A.O. Synthetic Strategies for Peroxide Ring Construction in Artemisinin. Molecules 2017, 22, 117. [CrossRef] [PubMed]

17. Peters, W. The problem of drug resistance in malaria. Parasitology 1985, 90, 705-715. [CrossRef] [PubMed] 
18. Ouji, M.; Augereau, J.-M.; Paloque, L.; Benoit-Vical, F. Plasmodium falciparum resistance to artemisinin-based combination therapies: A sword of Damocles in the path toward malaria elimination. Parasite 2018, 25, 24. [CrossRef]

19. Sun, W.C.; Han, J.X.; Yang, W.Y.; Deng, D.A.; Yue, X.F. Antitumor activities of 4 derivatives of artemisic acid and artemisinin B in vitro. Acta Pharmacol. Sin. 1992, 13, 541-543.

20. Woerdenbag, H.J.; Moskal, T.A.; Pras, N.; Malingré, T.M.; El-Feraly, F.S.; Kampinga, H.H.; Konings, A.W.T. Cytotoxicity of artemisinin-related endoperoxides to Ehrlich ascites tumor cells. J. Nat. Prod. 1993, 56, 849-856. [CrossRef]

21. Moore, J.C.; Lai, H.; Li, J.R.; Ren, R.L.; McDougall, J.A.; Singh, N.P.; Chou, C.K. Oral administration of dihydroartemisinin and ferrous sulfate retarded implanted fibrosarcoma growth in the rat. Cancer Lett. 1995, 98, 83-87. [CrossRef]

22. Manz, D.H.; Blanchette, N.L.; Paul, B.T.; Torti, F.M.; Torti, S.V. Iron and cancer: Recent insights. Ann. N. Y. Acad. Sci. 2016, 1368, 149-161. [CrossRef] [PubMed]

23. Adachi, M.; Kai, K.; Yamaji, K.; Ide, T.; Noshiro, H.; Kawaguchi, A.; Aishima, S. Transferrin receptor 1 overexpression is associated with tumour de-differentiation and acts as a potential prognostic indicator of hepatocellular carcinoma. Histopathology 2019, 75, 63-73. [CrossRef] [PubMed]

24. Bhaw-Luximon, A.; Jhurry, D. Artemisinin and its derivatives in cancer therapy: Status of progress, mechanism of action, and future perspectives. Cancer Chemother. Pharmacol. 2017, 79, 451-466. [CrossRef] [PubMed]

25. Conradt, B. Genetic control of programmed cell death during animal development. Annu. Rev. Genet. 2009, 43, 493-523. [CrossRef]

26. Galluzzi, L.; Vitale, I.; Aaronson, S.A.; Abrams, J.M.; Adam, D.; Agostinis, P.; Alnemri, E.S.; Altucci, L.; Amelio, I.; Andrews, D.W.; et al. Molecular mechanisms of cell death: Recommendations of the Nomenclature Committee on Cell Death 2018. Cell Death Differ. 2018, 25, 486-541.

27. Susan, E. Apoptosis: A Reveiw of Programmed Cell Death. Toxicol. Pathol. 2007, 35, 496-516.

28. Chaudhry, G.E.S.; Jan, R.; Zafar, M.N.; Mohammad, H.; Muhammad, T.S.T. Vitex Rotundifolia fractions induced apoptosis in human breast cancer T-47d cell line via activation of extrinsic and intrinsic pathway. Asian Pac. J. Cancer Prev. 2019, 20, 3555-3562. [CrossRef]

29. Fakai, M.I.; Abd Malek, S.N.; Karsani, S.A. Induction of apoptosis by chalepin through phosphatidylserine externalisations and DNA fragmentation in breast cancer cells (MCF7). Life Sci. 2019, 220, 186-193. [CrossRef]

30. Wu, S.; Zeng, L.; Wang, C.; Yang, Y.; Zhou, W.; Li, F.; Tan, Z. Assessment of the cytotoxicity of ionic liquids on Spodoptera frugiperda 9 (Sf-9) cell lines via in vitro assays. J. Hazard. Mater. 2018, 348, 1-9. [CrossRef]

31. Wang, D.; Fung, J.N.T.; Tuo, Y.; Hu, L.; Chen, C. TWEAK/Fn14 promotes apoptosis of human endometrial cancer cells via caspase pathway. Cancer Lett. 2010, 294, 91-100. [CrossRef]

32. Jiang, Y.; Yu, M.; Hu, X.; Han, L.; Yang, K.; Ba, H.; Zhang, Z.; Yin, B.; Yang, X.P.; Li, Z.; et al. STAT1 mediates transmembrane TNF-alpha-induced formation of death-inducing signaling complex and apoptotic signaling via TNFR1. Cell Death Differ. 2017, 24, 660-671. [CrossRef] [PubMed]

33. Yuan, X.; Gajan, A.; Chu, Q.; Xiong, H.; Wu, K.; Wu, G.S. Developing TRAIL/TRAIL death receptor-based cancer therapies. Cancer Metastasis Rev. 2018, 37, 733-748. [CrossRef] [PubMed]

34. Li, X.Z.; Lv, C.L.; Shi, J.G.; Zhang, C.X. MiR-543-3p promotes locomotor function recovery after spinal cord injury by inhibiting the expression of tumor necrosis factor superfamily member 15 in rats. Eur. Rev. Med. Pharmacol. Sci. 2019, 23, 2701-2709. [PubMed]

35. Yuan, Y.; Zhang, Y.; Zhao, S.; Chen, J.; Yang, J.; Wang, T.; Zou, H.; Wang, Y.; Gu, J.; Liu, X.; et al. Cadmium-induced apoptosis in neuronal cells is mediated by Fas/FasL-mediated mitochondrial apoptotic signaling pathway. Sci. Rep. 2018, 8, 8837. [CrossRef]

36. Suo, F.; Zhou, X.; Setroikromo, R.; Quax, W.J. Receptor Specificity Engineering of TNF Superfamily Ligands. Pharmaceutics 2022, 14, 181. [CrossRef]

37. Soto-Gamez, A.; Quax, W.J.; Demaria, M. Regulation of Survival Networks in Senescent Cells: From Mechanisms to Interventions. J. Mol. Biol. 2019, 431, 2629-2643. [CrossRef]

38. Deng, D.; Shah, K. TRAIL of Hope Meeting Resistance in Cancer. Trends Cancer 2020, 6, 989-1001. [CrossRef]

39. Liu, Q.; Xiao, S.; Xia, Y. TWEAK/Fn14 Activation Participates in Skin Inflammation. Mediat. Inflamm. 2017, $2017,6746870$. [CrossRef]

40. Nair, P.; Lu, M.; Petersen, S.; Ashkenazi, A. Apoptosis initiation through the cell-extrinsic pathway. In Methods in Enzymology Academic Press: Cambridge, MA, USA, 2014; Volume 544, pp. 99-128. ISBN 9780124171589.

41. Safa, A.; Day, T.; Wu, C.-H. Cellular FLICE-Like Inhibitory Protein (C-FLIP): A Novel Target for Cancer Therapy. Curr. Cancer Drug Targets 2008, 8, 37-46. [CrossRef]

42. Schug, Z.T.; Gonzalvez, F.; Houtkooper, R.H.; Vaz, F.M.; Gottlieb, E. BID is cleaved by caspase-8 within a native complex on the mitochondrial membrane. Cell Death Differ. 2011, 18, 538-548. [CrossRef]

43. Willms, A.; Schittek, H.; Rahn, S.; Sosna, J.; Mert, U.; Adam, D.; Trauzold, A. Impact of p53 status on TRAIL-mediated apoptotic and non-apoptotic signaling in cancer cells. PLoS ONE 2019, 14, e0214847. [CrossRef] [PubMed]

44. Boivin, W.A.; Cooper, D.M.; Hiebert, P.R.; Granville, D.J. Intracellular versus extracellular granzyme B in immunity and disease: Challenging the dogma. Lab. Investig. 2009, 89, 1195-1220. [CrossRef] [PubMed]

45. Nirmala, J.G.; Lopus, M. Cell death mechanisms in eukaryotes. Cell Biol. Toxicol. 2020, 36, 145-164. [CrossRef] [PubMed]

46. Efferth, T.; Rücker, G.; Falkenberg, M.; Manns, D.; Olbrich, A.; Fabry, U.; Osieka, R. Detection of apoptosis in KG-1a leukemic cells treated with investigational drugs. Arzneim. Forsch. 1996, 46, 196-200. 
47. Handrick, R.; Ontikatze, T.; Bauer, K.D.; Freier, F.; Rübel, A.; Dürig, J.; Belka, C.; Jendrossek, V. Dihydroartemisinin induces apoptosis by a bak-dependent intrinsic pathway. Mol. Cancer Ther. 2010, 9, 2497-2510. [CrossRef]

48. Im, E.; Yeo, C.; Lee, H.J.; Lee, E.O. Dihydroartemisinin induced caspase-dependent apoptosis through inhibiting the specificity protein 1 pathway in hepatocellular carcinoma SK-Hep-1 cells. Life Sci. 2018, 192, 286-292. [CrossRef]

49. Zhou, X.; Zijlstra, S.N.; Soto-Gamez, A.; Setroikromo, R.; Quax, W.J. Artemisinin Derivatives Stimulate DR5-Specific TRAILInduced Apoptosis by Regulating Wildtype P53. Cancers 2020, 12, 2514. [CrossRef]

50. Ilamathi, M.; Sivaramakrishnan, V. Artesunate acts as fuel to fire in sensitizing HepG2 cells towards TRAIL mediated apoptosis via STAT3 inhibition and DR4 augmentation. Biomed. Pharmacother. 2017, 88, 515-520. [CrossRef]

51. Wang, K.S.; Li, J.; Wang, Z.; Mi, C.; Ma, J.; Piao, L.X.; Xu, G.H.; Li, X.; Jin, X. Artemisinin inhibits inflammatory response via regulating NF- $\mathrm{KB}$ and MAPK signaling pathways. Immunopharmacol. Immunotoxicol. 2017, 39, 28-36. [CrossRef]

52. Ji, Y.; Zhang, Y.C.; Pei, L.B.; Shi, L.L.; Yan, J.L.; Ma, X.H. Anti-tumor effects of dihydroartemisinin on human osteosarcoma. Mol. Cell. Biochem. 2011, 351, 99-108. [CrossRef]

53. Greenshields, A.L.; Fernando, W.; Hoskin, D.W. The anti-malarial drug artesunate causes cell cycle arrest and apoptosis of triple-negative MDA-MB-468 and HER2-enriched SK-BR-3 breast cancer cells. Exp. Mol. Pathol. 2019, 107, 10-22. [CrossRef] [PubMed]

54. Sun, Q.; Wang, J.; Li, Y.; Zhuang, J.; Zhang, Q.; Sun, X.; Sun, D. Synthesis and evaluation of cytotoxic activities of artemisinin derivatives. Chem. Biol. Drug Des. 2017, 90, 1019-1028. [CrossRef] [PubMed]

55. Cabello, C.M.; Lamore, S.D.; Bair, W.B.; Qiao, S.; Azimian, S.; Lesson, J.L.; Wondrak, G.T. The redox antimalarial dihydroartemisinin targets human metastatic melanoma cells but not primary melanocytes with induction of NOXA-dependent apoptosis. Invest. New Drugs 2012, 30, 1289-1301. [CrossRef] [PubMed]

56. Hong, S.H.; Lee, D.H.; Lee, Y.S.; Jo, M.J.; Jeong, Y.A.; Kwon, W.T.; Choudry, H.A.; Bartlett, D.L.; Lee, Y.J. Molecular crosstalk between ferroptosis and apoptosis: Emerging role of ER stress-induced p53-independent PUMA expression. Oncotarget 2017, 8, 115164-115178. [CrossRef]

57. Mao, H.; Gu, H.; Qu, X.; Sun, J.; Song, B.; Gao, W.; Liu, J.; Shao, Q. Involvement of the mitochondrial pathway and Bim/Bcl-2 balance in dihydroartemisinin-induced apoptosis in human breast cancer in vitro. Int. J. Mol. Med. 2013, 31, 213-218. [CrossRef]

58. Poupel, F.; Aghaei, M.; Movahedian, A.; Jafari, S.; Shahrestanaki, M. Dihydroartemisinin induces apoptosis in human bladder cancer cell lines through reactive oxygen species, mitochondrial membrane potential, and cytochrome C pathway. Int. J. Prev. Med. 2017, 8, 78 .

59. Du, X.X.; Li, Y.J.; Wu, C.L.; Zhou, J.H.; Han, Y.; Sui, H.; Wei, X.L.; Liu, L.; Huang, P.; Yuan, H.H.; et al. Initiation of apoptosis, cell cycle arrest and autophagy of esophageal cancer cells by dihydroartemisinin. Biomed. Pharmacother. 2013, 67, 417-424. [CrossRef]

60. Qin, G.; Zhao, C.B.; Zhang, L.; Liu, H.; Quan, Y.; Chai, L.; Wu, S.; Wang, X.; Chen, T. Dihydroartemisinin induces apoptosis preferentially via a Bim-mediated intrinsic pathway in hepatocarcinoma cells. Apoptosis 2015, 20, 1072-1086. [CrossRef]

61. Hamacher-Brady, A.; Stein, H.A.; Turschner, S.; Toegel, I.; Mora, R.; Jennewein, N.; Efferth, T.; Eils, R.; Brady, N.R. Artesunate activates mitochondrial apoptosis in breast cancer cells via iron-catalyzed lysosomal reactive oxygen species production. J. Biol. Chem. 2011, 286, 6587-6601. [CrossRef]

62. Cao, Y.; Feng, Y.-H.; Gao, L.-W.; Li, X.-Y.; Jin, Q.-X.; Wang, Y.-Y.; Xu, Y.-Y.; Jin, F.; Lu, S.-L.; Wei, M.-J. Artemisinin enhances the anti-tumor immune response in $4 \mathrm{~T} 1$ breast cancer cells in vitro and in vivo. Int. Immunopharmacol. 2019, 70, 110-116. [CrossRef]

63. Zhou, Z.-H.; Chen, F.-X.; Xu, W.-R.; Qian, H.; Sun, L.-Q.; Lü, X.-T.; Chen, L.; Zhang, J.; Ji, H.-C.; Fei, S.-J. Enhancement effect of dihydroartemisinin on human $\gamma \delta \mathrm{T}$ cell proliferation and killing pancreatic cancer cells. Int. Immunopharmacol. 2013, 17, 850-857. [CrossRef] [PubMed]

64. Dixon, S.J.; Lemberg, K.M.; Lamprecht, M.R.; Skouta, R.; Zaitsev, E.M.; Gleason, C.E.; Patel, D.N.; Bauer, A.J.; Cantley, A.M.; Yang, W.S.; et al. Ferroptosis: An iron-dependent form of nonapoptotic cell death. Cell 2012, 149, 1060-1072. [CrossRef] [PubMed]

65. Li, J.; Cao, F.; Yin, H.; Huang, Z.; Lin, Z.; Mao, N.; Sun, B.; Wang, G. Ferroptosis: Past, present and future. Cell Death Dis. 2020, 11, 88. [CrossRef] [PubMed]

66. Dixon, S.J.; Stockwell, B.R. The hallmarks of ferroptosis. Annu. Rev. Cancer Biol. 2019, 3, 35-54. [CrossRef]

67. Zhang, L.; Liu, W.; Liu, F.; Wang, Q.; Song, M.; Yu, Q.; Tang, K.; Teng, T.; Wu, D.; Wang, X.; et al. IMCA Induces Ferroptosis Mediated by SLC7A11 through the AMPK/mTOR Pathway in Colorectal Cancer. Oxid. Med. Cell. Longev. 2020, $2020,1675613$. [CrossRef] [PubMed]

68. Battaglia, A.M.; Chirillo, R.; Aversa, I.; Sacco, A.; Costanzo, F.; Biamonte, F. Ferroptosis and Cancer: Mitochondria Meet the "Iron Maiden" Cell Death. Cells 2020, 9, 1505. [CrossRef]

69. Hassannia, B.; Vandenabeele, P.; Vanden Berghe, T. Targeting Ferroptosis to Iron Out Cancer. Cancer Cell 2019, 35, 830-849. [CrossRef]

70. Kannan, D.; Yadav, N.; Ahmad, S.; Namdev, P.; Bhattacharjee, S.; Lochab, B.; Singh, S. Pre-clinical study of iron oxide nanoparticles fortified artesunate for efficient targeting of malarial parasite. EBioMedicine 2019, 45, 261-277. [CrossRef]

71. Li, D.; Zhang, J.; Zhao, X. Mechanisms and Molecular Targets of Artemisinin in Cancer Treatment. Cancer Investig. 2021, 39, 675-684. [CrossRef]

72. Yi, R.; Wang, H.; Deng, C.; Wang, X.; Yao, L.; Niu, W.; Fei, M.; Zhaba, W. Dihydroartemisinin initiates ferroptosis in glioblastoma through GPX4 inhibition. Biosci. Rep. 2020, 40, BSR20193314. [CrossRef] 
73. Du, J.; Wang, T.; Li, Y.; Zhou, Y.; Wang, X.; Yu, X.; Ren, X.; An, Y.; Wu, Y.; Sun, W.; et al. DHA inhibits proliferation and induces ferroptosis of leukemia cells through autophagy dependent degradation of ferritin. Free Radic. Biol. Med. 2019, 131, 356-369. [CrossRef]

74. Wang, Z.; Li, M.; Liu, Y.; Qiao, Z.; Bai, T.; Yang, L.; Liu, B. Dihydroartemisinin triggers ferroptosis in primary liver cancer cells by promoting and unfolded protein response-induced upregulation of CHAC1 expression. Oncol. Rep. 2021, 46, 240. [CrossRef] [PubMed]

75. Chen, Y.; Mi, Y.; Zhang, X.; Ma, Q.; Song, Y.; Zhang, L.; Wang, D.; Xing, J.; Hou, B.; Li, H.; et al. Dihydroartemisinin-induced unfolded protein response feedback attenuates ferroptosis via PERK/ATF4/HSPA5 pathway in glioma cells. J. Exp. Clin. Cancer Res. 2019, 38, 402. [CrossRef] [PubMed]

76. Eling, N.; Reuter, L.; Hazin, J.; Hamacher-Brady, A.; Brady, N.R. Identification of artesunate as a specific activator of ferroptosis in pancreatic cancer cells. Oncoscience 2015, 2, 517-532. [CrossRef]

77. Zhang, Q.; Yi, H.; Yao, H.; Lu, L.; He, G.; Wu, M.; Zheng, C.; Li, Y.; Chen, S.; Li, L.; et al. Artemisinin derivatives inhibit Non-small cell lung cancer cells through induction of ROS-dependent apoptosis/ferroptosis. J. Cancer 2021, 12, 4075-4085. [CrossRef]

78. Ishikawa, C.; Senba, M.; Mori, N. Evaluation of artesunate for the treatment of adult T-cell leukemia/lymphoma. Eur. J. Pharmacol. 2020, 872, 172953. [CrossRef] [PubMed]

79. Chen, G.-Q.; Benthani, F.A.; Wu, J.; Liang, D.; Bian, Z.-X.; Jiang, X. Artemisinin compounds sensitize cancer cells to ferroptosis by regulating iron homeostasis. Cell Death Differ. 2020, 27, 242-254. [CrossRef]

80. Zou, Y.; Schreiber, S.L. Progress in Understanding Ferroptosis and Challenges in Its Targeting for Therapeutic Benefit. Cell Chem. Biol. 2020, 27, 463-471. [CrossRef]

81. Ooko, E.; Saeed, M.E.M.; Kadioglu, O.; Sarvi, S.; Colak, M.; Elmasaoudi, K.; Janah, R.; Greten, H.J.; Efferth, T. Artemisinin derivatives induce iron-dependent cell death (ferroptosis) in tumor cells. Phytomedicine 2015, 22, 1045-1054. [CrossRef]

82. Lin, R.; Zhang, Z.; Chen, L.; Zhou, Y.; Zou, P.; Feng, C.; Wang, L.; Liang, G. Dihydroartemisinin (DHA) induces ferroptosis and causes cell cycle arrest in head and neck carcinoma cells. Cancer Lett. 2016, 381, 165-175. [CrossRef]

83. Wang, N.; Zeng, G.Z.; Yin, J.L.; Bian, Z.X. Artesunate activates the ATF4-CHOP-CHAC1 pathway and affects ferroptosis in Burkitt's Lymphoma. Biochem. Biophys. Res. Commun. 2019, 519, 533-539. [CrossRef] [PubMed]

84. Wang, K.; Zhang, Z.; Wang, M.; Cao, X.; Qi, J.; Wang, D.; Gong, A.; Zhu, H. Role of GRP78 inhibiting artesunate-induced ferroptosis in KRAS mutant pancreatic cancer cells. Drug Des. Devel. Ther. 2019, 13, 2135-2144. [CrossRef] [PubMed]

85. Chen, Y.; Wang, F.; Wu, P.; Gong, S.; Gao, J.; Tao, H.; Shen, Q.; Wang, S.; Zhou, Z.; Jia, Y. Artesunate induces apoptosis, autophagy and ferroptosis in diffuse large B cell lymphoma cells by impairing STAT3 signaling. Cell. Signal. 2021, 88, 110167. [CrossRef] [PubMed]

86. Kenney, D.L.; Benarroch, E.E. The autophagy-lysosomal pathway. Neurology 2015, 85, 634-645. [CrossRef] [PubMed]

87. Papandreou, I.; Lim, A.L.; Laderoute, K.; Denko, N.C. Hypoxia signals autophagy in tumor cells via AMPK activity, independent of HIF-1, BNIP3, and BNIP3L. Cell Death Differ. 2008, 15, 1572-1581. [CrossRef] [PubMed]

88. Fang, Y.; Tan, J.; Zhang, Q. Signaling pathways and mechanisms of hypoxia-induced autophagy in the animal cells. Cell Biol. Int. 2015, 39, 891-898. [CrossRef] [PubMed]

89. Zhang, Y.; Zhang, Y.; Jin, X.F.; Zhou, X.H.; Dong, X.H.; Yu, W.T.; Gao, W.J. The role of Astragaloside IV against cerebral ischemia/reperfusion injury: Suppression of apoptosis via promotion of P62-LC3-autophagy. Molecules 2019, 24, 1838. [CrossRef]

90. Randall-Demllo, S.; Chieppa, M.; Eri, R. Intestinal Epithelium and Autophagy: Partners in Gut Homeostasis. Front. Immunol. 2013, 4, 301. [CrossRef]

91. Hansen, M.; Rubinsztein, D.C.; Walker, D.W. Autophagy as a promoter of longevity: Insights from model organisms. Nat. Rev. Mol. Cell Biol. 2018, 19, 579-593. [CrossRef]

92. Mizushima, N.; Komatsu, M. Autophagy: Renovation of cells and tissues. Cell 2011, 147, 728-741. [CrossRef]

93. Zou, J.; Ma, Q.; Sun, R.; Cai, J.; Liao, H.; Xu, L.; Xia, J.; Huang, G.; Yao, L.; Cai, Y.; et al. Dihydroartemisinin inhibits HepG2.2.15 proliferation by inducing cellular senescence and autophagy. BMB Rep. 2019, 52, 520-525. [CrossRef] [PubMed]

94. Zhou, X.; Chen, Y.; Wang, F.; Wu, H.; Zhang, Y.; Liu, J.; Cai, Y.; Huang, S.; He, N.; Hu, Z.; et al. Artesunate induces autophagy dependent apoptosis through upregulating ROS and activating AMPK-mTOR-ULK1 axis in human bladder cancer cells. Chem. Biol. Interact. 2020, 331, 109273. [CrossRef] [PubMed]

95. Jia, G.; Kong, R.; Ma, Z.-B.; Han, B.; Wang, Y.-W.; Pan, S.-H.; Li, Y.-H.; Sun, B. The activation of c-Jun $\mathrm{NH}_{2}$-terminal kinase is required for dihydroartemisinin-induced autophagy in pancreatic cancer cells. J. Exp. Clin. Cancer Res. 2014, 33, 8. [CrossRef]

96. Jiang, F.; Zhou, J.Y.; Zhang, D.; Liu, M.H.; Chen, Y.G. Artesunate induces apoptosis and autophagy in HCT116 colon cancer cells, and autophagy inhibition enhances the artesunate-induced apoptosis. Int. J. Mol. Med. 2018, 42, 1295-1304. [CrossRef] [PubMed]

97. Cheng, C.; Wang, T.; Song, Z.; Peng, L.; Gao, M.; Hermine, O.; Rousseaux, S.; Khochbin, S.; Mi, J.-Q.; Wang, J. Induction of autophagy and autophagy-dependent apoptosis in diffuse large B-cell lymphoma by a new antimalarial artemisinin derivative, SM1044. Cancer Med. 2018, 7, 380-396. [CrossRef] [PubMed]

98. Li, B.; Bu, S.; Sun, J.; Guo, Y.; Lai, D. Artemisinin derivatives inhibit epithelial ovarian cancer cells via autophagy-mediated cell cycle arrest. Acta Biochim. Biophys. Sin. 2018, 50, 1227-1235. [CrossRef]

99. Thongchot, S.; Vidoni, C.; Ferraresi, A.; Loilome, W.; Yongvanit, P.; Namwat, N.; Isidoro, C. Dihydroartemisinin induces apoptosis and autophagy-dependent cell death in cholangiocarcinoma through a DAPK1-BECLIN1 pathway. Mol. Carcinog. 2018, 57, 1735-1750. [CrossRef] 
100. Wang, Z.; Hu, W.; Zhang, J.-L.; Wu, X.-H.; Zhou, H.-J. Dihydroartemisinin induces autophagy and inhibits the growth of iron-loaded human myeloid leukemia K562 cells via ROS toxicity. FEBS Open Bio 2012, 2, 103-112. [CrossRef]

101. Hu, W.; Chen, S.-S.; Zhang, J.-L.; Lou, X.-E.; Zhou, H.-J. Dihydroartemisinin induces autophagy by suppressing NF- $\kappa B$ activation. Cancer Lett. 2014, 343, 239-248. [CrossRef]

102. Shi, X.; Wang, L.; Li, X.; Bai, J.; Li, J.; Li, S.; Wang, Z.; Zhou, M. Dihydroartemisinin induces autophagy-dependent death in human tongue squamous cell carcinoma cells through DNA double-strand break-mediated oxidative stress. Oncotarget 2017, 8, 45981-45993. [CrossRef]

103. Liu, X.; Wu, J.; Fan, M.; Shen, C.; Dai, W.; Bao, Y.; Liu, J.-H.; Yu, B.-Y. Novel dihydroartemisinin derivative DHA-37 induces autophagic cell death through upregulation of HMGB1 in A549 cells. Cell Death Dis. 2018, 9, 1048. [CrossRef]

104. Shi, X.; Wang, L.; Ren, L.; Li, J.; Li, S.; Cui, Q.; Li, S. Dihydroartemisinin, an antimalarial drug, induces absent in melanoma 2 inflammasome activation and autophagy in human hepatocellular carcinoma HepG2215 cells. Phyther. Res. 2019, 33, 1413-1425. [CrossRef]

105. Wang, L.; Li, J.; Shi, X.; Li, S.; Tang, P.M.K.; Li, Z.; Li, H.; Wei, C. Antimalarial Dihydroartemisinin triggers autophagy within HeLa cells of human cervical cancer through Bcl-2 phosphorylation at Ser70. Phytomedicine 2019, 52, 147-156. [CrossRef]

106. Ma, Q.; Liao, H.; Xu, L.; Li, Q.; Zou, J.; Sun, R.; Xiao, D.; Liu, C.; Pu, W.; Cheng, J.; et al. Autophagy-dependent cell cycle arrest in esophageal cancer cells exposed to dihydroartemisinin. Chin. Med. 2020, 15, 37. [CrossRef]

107. Shi, X.; Li, S.; Wang, L.; Li, H.; Li, Z.; Wang, W.; Bai, J.; Sun, Y.; Li, J.; Li, X. RalB degradation by dihydroartemisinin induces autophagy and IFI16/caspase-1 inflammasome depression in the human laryngeal squamous cell carcinoma. Chin. Med. 2020, 15, 64. [CrossRef] [PubMed]

108. Chen, X.; He, L.-Y.; Lai, S.; He, Y. Dihydroartemisinin inhibits the migration of esophageal cancer cells by inducing autophagy Oncol. Lett. 2020, 20, 94. [CrossRef] [PubMed]

109. Yan, G.; Dawood, M.; Böckers, M.; Klauck, S.M.; Fottner, C.; Weber, M.M.; Efferth, T. Multiple modes of cell death in neuroendocrine tumors induced by artesunate. Phytomedicine 2020, 79, 153332. [CrossRef] [PubMed]

110. Zhang, J.; Zhou, L.; Xiang, J.-D.; Jin, C.-S.; Li, M.-Q.; He, Y.-Y. Artesunate-induced ATG5-related autophagy enhances the cytotoxicity of NK92 cells on endometrial cancer cells via interactions between CD155 and CD226/TIGIT. Int. Immunopharmacol. 2021, 97, 107705. [CrossRef] [PubMed]

111. Frank, D.; Vince, J.E. Pyroptosis versus necroptosis: Similarities, differences, and crosstalk. Cell Death Differ. 2019, 26, 99-114. [CrossRef] [PubMed]

112. Fritsch, M.; Günther, S.D.; Schwarzer, R.; Albert, M.C.; Schorn, F.; Werthenbach, J.P.; Schiffmann, L.M.; Stair, N.; Stocks, H.; Seeger, J.M.; et al. Caspase-8 is the molecular switch for apoptosis, necroptosis and pyroptosis. Nature 2019, 575, 683-687. [CrossRef]

113. Laurien, L.; Nagata, M.; Schünke, H.; Delanghe, T.; Wiederstein, J.L.; Kumari, S.; Schwarzer, R.; Corona, T.; Krüger, M.; Bertrand, M.J.M.; et al. Autophosphorylation at serine 166 regulates RIP kinase 1-mediated cell death and inflammation. Nat. Commun. 2020, 11, 1747. [CrossRef] [PubMed]

114. Zanetti, L.C.; Weinlich, R. Necroptosis, the Other Main Caspase-Independent Cell Death. In Advances in Experimental Medicine and Biology; Springer: Cham, Switzerland, 2021; Volume 1301, pp. 123-138.

115. Button, R.W.; Lin, F.; Ercolano, E.; Vincent, J.H.; Hu, B.; Hanemann, C.O.; Luo, S. Artesunate induces necrotic cell death in schwannoma cells. Cell Death Dis. 2014, 5, e1466. [CrossRef] [PubMed]

116. Chauhan, A.K.; Min, K.-J.; Kwon, T.K. RIP1-dependent reactive oxygen species production executes artesunate-induced cell death in renal carcinoma Caki cells. Mol. Cell. Biochem. 2017, 435, 15-24. [CrossRef] [PubMed]

117. Lei, X.Y.; Tan, R.Z.; Jia, J.; Wu, S.L.; Wen, C.L.; Lin, X.; Wang, H.; Shi, Z.J.; Li, B.; Kang, Y.; et al. Artesunate relieves acute kidney injury through inhibiting macrophagic Mincle-mediated necroptosis and inflammation to tubular epithelial cell. J. Cell. Mol. Med. 2021, 25, 8775-8788. [CrossRef]

118. Li, Y.; Wang, W.; Li, A.; Huang, W.; Chen, S.; Han, F.; Wang, L. Dihydroartemisinin induces pyroptosis by promoting the AIM2/caspase-3/DFNA5 axis in breast cancer cells. Chem. Biol. Interact. 2021, 340, 109434. [CrossRef]

119. Jiang, M.; Wu, Y.; Qi, L.; Li, L.; Song, D.; Gan, J.; Li, Y.; Ling, X.; Song, C. Dihydroartemisinin mediating PKM2-caspase-8/3GSDME axis for pyroptosis in esophageal squamous cell carcinoma. Chem. Biol. Interact. 2021, 350, 109704. [CrossRef]

120. Yu, P.; Zhang, X.; Liu, N.; Tang, L.; Peng, C.; Chen, X. Pyroptosis: Mechanisms and diseases. Signal Transduct. Target. Ther. 2021, 6, 128. [CrossRef]

121. Wang, L.; Qin, X.; Liang, J.; Ge, P. Induction of Pyroptosis: A Promising Strategy for Cancer Treatment. Front. Oncol. 2021, 11, 635774. [CrossRef]

122. Xia, X.; Wang, X.; Cheng, Z.; Qin, W.; Lei, L.; Jiang, J.; Hu, J. The role of pyroptosis in cancer: Pro-cancer or pro-"host"? Cell Death Dis. 2019, 10, 650. [CrossRef]

123. Fang, Y.; Tian, S.; Pan, Y.; Li, W.; Wang, Q.; Tang, Y.; Yu, T.; Wu, X.; Shi, Y.; Ma, P.; et al. Pyroptosis: A new frontier in cancer. Biomed. Pharmacother. 2020, 121, 109595. [CrossRef]

124. Rogers, C.; Fernandes-Alnemri, T.; Mayes, L.; Alnemri, D.; Cingolani, G.; Alnemri, E.S. Cleavage of DFNA5 by caspase-3 during apoptosis mediates progression to secondary necrotic/pyroptotic cell death. Nat. Commun. 2017, 8, 14128. [CrossRef]

125. Wang, Y.; Gao, W.; Shi, X.; Ding, J.; Liu, W.; He, H.; Wang, K.; Shao, F. Chemotherapy drugs induce pyroptosis through caspase-3 cleavage of a gasdermin. Nature 2017, 547, 99-103. [CrossRef] [PubMed] 
126. Sauter, E.R. Cancer prevention and treatment using combination therapy with natural compounds. Expert Rev. Clin. Pharmacol. 2020, 13, 265-285. [CrossRef] [PubMed]

127. Wang, J.; Su, S.; Li, J.; Li, Y. Efficacy and Safety of Camrelizumab Monotherapy and Combination Therapy for Cancers: A Systematic Review and Meta-Analysis. Front. Oncol. 2021, 11, 695512. [CrossRef]

128. Mokhtari, R.B.; Homayouni, T.S.; Baluch, N.; Morgatskaya, E.; Kumar, S.; Das, B.; Yeger, H. Combination therapy in combating cancer. Oncotarget 2017, 8, 38022-38043. [CrossRef] [PubMed]

129. Soto-Gamez, A.; Wang, Y.; Zhou, X.; Seras, L.; Quax, W.; Demaria, M. Enhanced extrinsic apoptosis of therapy-induced senescent cancer cells using a death receptor 5 (DR5) selective agonist. Cancer Lett. 2022, 525, 67-75. [CrossRef] [PubMed]

130. Mitsiades, C.S.; Treon, S.P.; Mitsiades, N.; Shima, Y.; Richardson, P.; Schlossman, R.; Hideshima, T.; Anderson, K.C. TRAIL/ Apo2L ligand selectively induces apoptosis and overcomes drug resistance in multiple myeloma: Therapeutic applications. Blood 2001, 98, 795-804. [CrossRef]

131. Snajdauf, M.; Havlova, K.; Vachtenheim, J.; Ozaniak, A.; Lischke, R.; Bartunkova, J.; Smrz, D.; Strizova, Z. The TRAIL in the Treatment of Human Cancer: An Update on Clinical Trials. Front. Mol. Biosci. 2021, 8, 628332. [CrossRef]

132. Van Dijk, M.; Halpin-McCormick, A.; Sessler, T.; Samali, A.; Szegezdi, E. Resistance to TRAIL in non-transformed cells is due to multiple redundant pathways. Cell Death Dis. 2013, 4, e702. [CrossRef]

133. Zhang, L.; Fang, B. Mechanisms of resistance to TRAIL-induced apoptosis in cancer. Cancer Gene Ther. 2005, 12, 228-237. [CrossRef]

134. He, Q.; Shi, J.; Shen, X.L.; An, J.; Sun, H.; Wang, L.; Hu, Y.J.; Sun, Q.; Fu, L.C.; Sheikh, M.S.; et al. Dihydroartemisinin upregulates death receptor 5 expression and cooperates with TRAIL to induce apoptosis in human prostate cancer cells. Cancer Biol. Ther. 2010, 9, 819-824. [CrossRef] [PubMed]

135. Kong, R.; Jia, G.; Cheng, Z.; Wang, Y.; Mu, M.; Wang, S.; Pan, S.; Gao, Y.; Jiang, H.; Dong, D.; et al. Dihydroartemisinin enhances Apo2L/TRAIL-mediated apoptosis in pancreatic cancer cells via ROS-mediated up-regulation of death receptor 5. PLoS ONE 2012, 7, e37222. [CrossRef]

136. Yan, N.; Zhang, J. Iron Metabolism, Ferroptosis, and the Links With Alzheimer's Disease. Front. Neurosci. 2019, 13, 1443. [CrossRef] [PubMed]

137. Feng, H.; Schorpp, K.; Jin, J.; Yozwiak, C.E.; Hoffstrom, B.G.; Decker, A.M.; Rajbhandari, P.; Stokes, M.E.; Bender, H.G.; Csuka, J.M.; et al. Transferrin Receptor Is a Specific Ferroptosis Marker. Cell Rep. 2020, 30, 3411-3423.e7. [CrossRef]

138. Högemann-Savellano, D.; Bost, E.; Blondet, C.; Sato, F.; Abe, T.; Josephson, L.; Weissleder, R.; Gaudet, J.; Sgroi, D.; Peters, P.J.; et al. The Transferrin Receptor: A Potential Molecular Imaging Marker for Human Cancer. Neoplasia 2003, 5, 495-506. [CrossRef]

139. Lai, H.; Singh, N.P. Selective cancer cell cytotoxicity from exposure to dihydroartemisinin and holotransferrin. Cancer Lett. 1995, 91, 41-46. [CrossRef]

140. Sadava, D.; Phillips, T.; Lin, C.; Kane, S.E. Transferrin overcomes drug resistance to artemisinin in human small-cell lung carcinoma cells. Cancer Lett. 2002, 179, 151-156. [CrossRef]

141. Efferth, T.; Benakis, A.; Romero, M.R.; Tomicic, M.; Rauh, R.; Steinbach, D.; Häfer, R.; Stamminger, T.; Oesch, F.; Kaina, B.; et al. Enhancement of cytotoxicity of artemisinins toward cancer cells by ferrous iron. Free Radic. Biol. Med. 2004, 37, 998-1009. [CrossRef]

142. Deng, X.R.; Liu, Z.X.; Liu, F.; Pan, L.; Yu, H.P.; Jiang, J.P.; Zhang, J.J.; Liu, L.; Yu, J. Holotransferrin enhances selective anticancer activity of artemisinin against human hepatocellular carcinoma cells. J. Huazhong Univ. Sci. Technol.-Med. Sci. 2013, 33, 862-865. [CrossRef]

143. Wang, Q.; Wu, S.; Zhao, X.; Zhao, C.; Zhao, H.; Huo, L. Mechanisms of Dihydroartemisinin and Dihydroartemisinin/Holotransferrin Cytotoxicity in T-Cell Lymphoma Cells. PLoS ONE 2015, 10, e0137331.

144. Lai, H.; Sasaki, T.; Singh, N.P.; Messay, A. Effects of artemisinin-tagged holotransferrin on cancer cells. Life Sci. 2005, 76, 1267-1279. [CrossRef]

145. Lai, H.; Nakase, I.; Lacoste, E.; Singh, N.P.; Sasaki, T. Artemisinin-transferrin conjugate retards growth of breast tumors in the rat. Anticancer Res. 2009, 29, 3807-3810.

146. Nakase, I.; Gallis, B.; Takatani-Nakase, T.; Oh, S.; Lacoste, E.; Singh, N.P.; Goodlett, D.R.; Tanaka, S.; Futaki, S.; Lai, H.; et al. Transferrin receptor-dependent cytotoxicity of artemisinin-transferrin conjugates on prostate cancer cells and induction of apoptosis. Cancer Lett. 2009, 274, 290-298. [CrossRef]

147. Zhou, X.; Soto-Gamez, A.; Nijdam, F.; Setroikromo, R.; Quax, W.J. Dihydroartemisinin-Transferrin Adducts Enhance TRAILInduced Apoptosis in Triple-Negative Breast Cancer in a P53-Independent and ROS-Dependent Manner. Front. Oncol. 2021, 11, 789336. [CrossRef] [PubMed]

148. Sieber, S.; Gdynia, G.; Roth, W.; Bonavida, B.; Efferth, T. Combination treatment of malignant B cells using the anti-CD20 antibody rituximab and the anti-malarial artesunate. Int. J. Oncol. 2009, 35, 149-158. [PubMed]

149. Zeng, X.; Li, Y.; Fan, J.; Zhao, H.; Xian, Z.; Sun, Y.; Wang, Z.; Wang, S.; Zhang, G.; Ju, D. Recombinant human arginase induced caspase-dependent apoptosis and autophagy in non-Hodgkin's lymphoma cells. Cell Death Dis. 2013, 4, e840. [CrossRef] [PubMed]

150. Lin, C.; Wang, Z.; Li, L.; He, Y.; Fan, J.; Liu, Z.; Zhao, S.; Ju, D. The role of autophagy in the cytotoxicity induced by recombinant human arginase in laryngeal squamous cell carcinoma. Appl. Microbiol. Biotechnol. 2015, 99, 8487-8494. [CrossRef] [PubMed] 
151. Wang, Z.; Shi, X.; Li, Y.; Zeng, X.; Fan, J.; Sun, Y.; Xian, Z.; Zhang, G.; Wang, S.; Hu, H.; et al. Involvement of autophagy in recombinant human arginase-induced cell apoptosis and growth inhibition of malignant melanoma cells. Appl. Microbiol. Biotechnol. 2014, 98, 2485-2494. [CrossRef]

152. Medhi, B.; Patyar, S.; Rao, R.S.; Byrav DS, P.; Prakash, A. Pharmacokinetic and Toxicological Profile of Artemisinin Compounds: An Update. Pharmacology 2009, 84, 323-332. [CrossRef]

153. Chen, J.; Zhang, W.; Zhang, M.; Guo, Z.; Wang, H.; He, M.; Xu, P.; Zhou, J.; Liu, Z.; Chen, Q. Mn(ii) mediated degradation of artemisinin based on $\mathrm{Fe}_{3} \mathrm{O}_{4} @ \mathrm{MnSiO}_{3}$-FA nanospheres for cancer therapy in vivo. Nanoscale 2015, 7, 12542-12551. [CrossRef]

154. Wang, D.; Zhou, J.; Chen, R.; Shi, R.; Xia, G.; Zhou, S.; Liu, Z.; Zhang, N.Q.; Wang, H.; Guo, Z.; et al. Magnetically guided delivery of DHA and Fe ions for enhanced cancer therapy based on pH-responsive degradation of DHA-loaded Fe $\mathrm{O}_{4} @ \mathrm{C} @ \mathrm{MIL}-100(\mathrm{Fe})$ nanoparticles. Biomaterials 2016, 107, 88-101. [CrossRef] [PubMed]

155. Wang, D.; Zhou, J.; Chen, R.; Shi, R.; Zhao, G.; Xia, G.; Li, R.; Liu, Z.; Tian, J.; Wang, H.H.; et al. Controllable synthesis of dual-MOFs nanostructures for $\mathrm{pH}$-responsive artemisinin delivery, magnetic resonance and optical dual-model imaging-guided chemo/photothermal combinational cancer therapy. Biomaterials 2016, 100, 27-40. [CrossRef] [PubMed]

156. Zhang, H.; Zhang, H.; Zhu, X.; Zhang, X.; Chen, Q.; Chen, J.; Hou, L.; Zhang, Z. Visible-light-sensitive titanium dioxide nanoplatform for tumor-responsive Fe2+ liberating and artemisinin delivery. Oncotarget 2017, 8, 58738-58753. [CrossRef] [PubMed]

157. Liu, L.; Liu, Y.; Ma, L.; Mao, F.; Jiang, A.; Liu, D.; Wang, L.; Jia, Q.; Zhou, J. Artemisinin-Loaded Mesoporous Nanoplatform for pH-Responsive Radical Generation Synergistic Tumor Theranostics. ACS Appl. Mater. Interfaces 2018, 10, 6155-6167. [CrossRef] [PubMed]

158. Pan, U.N.; Sanpui, P.; Paul, A.; Chattopadhyay, A. Synergistic Anticancer Potential of Artemisinin When Loaded with 8Hydroxyquinoline-Surface Complexed-Zinc Ferrite Magnetofluorescent Nanoparticles and Albumin Composite. ACS Appl. Bio Mater. 2018, 1, 1229-1235. [CrossRef]

159. Qin, X.; Zhang, H.; Wang, Z.; Jin, Y. $\mathrm{Fe}_{3} \mathrm{O}_{4} @ \mathrm{SiO}_{2}$ mesoporous spheres as $\mathrm{Fe}(\mathrm{ii})$ donors loaded with artemisinin and a photosensitizer to alleviate tumor hypoxia in PDT for enhanced anticancer therapy. New J. Chem. 2019, 43, 8761-8773. [CrossRef]

160. Luo, Y.; Sun, X.; Huang, L.; Yan, J.; Yu, B.Y.; Tian, J. Artemisinin-Based Smart Nanomedicines with Self-Supply of Ferrous Ion to Enhance Oxidative Stress for Specific and Efficient Cancer Treatment. ACS Appl. Mater. Interfaces 2019, 11, $29490-29497$. [CrossRef]

161. Guo, S.; Yao, X.; Jiang, Q.; Wang, K.; Zhang, Y.; Peng, H.; Tang, J.; Yang, W. Dihydroartemisinin-Loaded Magnetic Nanoparticles for Enhanced Chemodynamic Therapy. Front. Pharmacol. 2020, 11, 226. [CrossRef]

162. Zhang, H.; Li, M.; Zhu, X.; Zhang, Z.; Huang, H.; Hou, L. Artemisinin co-delivery system based on manganese oxide for precise diagnosis and treatment of breast cancer. Nanotechnology 2021, 32, 325101. [CrossRef]

163. Dadgar, N.; Alavi, S.E.; Esfahani, M.K.M.; Akbarzadeh, A. Study of toxicity effect of pegylated nanoliposomal artemisinin on breast cancer cell line. Indian I. Clin. Biochem. 2013, 28, 410-412. [CrossRef]

164. Righeschi, C.; Coronnello, M.; Mastrantoni, A.; Isacchi, B.; Bergonzi, M.C.; Mini, E.; Bilia, A.R. Strategy to provide a useful solution to effective delivery of dihydroartemisinin: Development, characterization and in vitro studies of liposomal formulations Colloids Surf. B Biointerfaces 2014, 116, 121-127. [CrossRef] [PubMed]

165. Li, X.Y.; Zhao, Y.; Sun, M.G.; Shi, J.F.; Ju, R.J.; Zhang, C.X.; Li, X.T.; Zhao, W.Y.; Mu, L.M.; Zeng, F.; et al. Multifunctional liposomes loaded with paclitaxel and artemether for treatment of invasive brain glioma. Biomaterials 2014, 35, 5591-5604. [CrossRef] [PubMed]

166. Gharib, A.; Faezizadeh, Z.; Mesbah-Namin, S.A.R.; Saravani, R. Experimental treatment of breast cancer-bearing BALB/c mice by artemisinin and transferrin-loaded magnetic nanoliposomes. Pharmacogn. Mag. 2015, 11, 117-122. [CrossRef] [PubMed]

167. Zhang, Y.J.; Zhan, X.; Wang, L.; Ho, R.J.Y.; Sasaki, T. pH-responsive artemisinin dimer in lipid nanoparticles are effective against human breast cancer in a xenograft model. J. Pharm. Sci. 2015, 104, 1815-1824. [CrossRef] [PubMed]

168. Fu, J.; Zhu, Y. Lysosomes activating chain reactions against cancer cells with a pH-switched prodrug/procatalyst co-delivery nanosystem. J. Mater. Chem. B 2017, 5, 996-1004. [CrossRef] [PubMed]

169. Hu, Y.J.; Zhang, J.Y.; Luo, Q.; Xu, J.R.; Yan, Y.; Mu, L.M.; Bai, J.; Lu, W.L. Nanostructured dihydroartemisinin plus epirubicin liposomes enhance treatment efficacy of breast cancer by inducing autophagy and apoptosis. Nanomaterials 2018, 8, 804. [CrossRef]

170. Ju, R.J.; Cheng, L.; Peng, X.M.; Wang, T.; Li, C.Q.; Song, X.L.; Liu, S.; Chao, J.P.; Li, X.T. Octreotide-modified liposomes containing daunorubicin and dihydroartemisinin for treatment of invasive breast cancer. Artif. Cells, Nanomed. Biotechnol. 2018, 46, 616-628. [CrossRef]

171. Gao, Z.; Li, Y.; You, C.; Sun, K.; An, P.; Sun, C.; Wang, M.; Zhu, X.; Sun, B. Iron oxide nanocarrier-mediated combination therapy of cisplatin and artemisinin for combating drug resistance through highly increased toxic reactive oxygen species generation. ACS Appl. Bio Mater. 2018, 1, 270-280. [CrossRef]

172. Li, H.; Li, X.; Shi, X.; Li, Z.; Sun, Y. Effects of magnetic dihydroartemisinin nano-liposome in inhibiting the proliferation of head and neck squamous cell carcinomas. Phytomedicine 2019, 56, 215-228. [CrossRef]

173. Wang, Z.; Duan, X.; Lv, Y.; Zhao, Y. Low density lipoprotein receptor (LDLR)-targeted lipid nanoparticles for the delivery of sorafenib and Dihydroartemisinin in liver cancers. Life Sci. 2019, 239, 117013. [CrossRef] 
174. Liu, J.J.; Tang, W.; Fu, M.; Gong, X.Q.; Kong, L.; Yao, X.M.; Jing, M.; Cai, F.Y.; Li, X.T.; Ju, R.J. Development of R 8 modified epirubicin-dihydroartemisinin liposomes for treatment of non-small-cell lung cancer. Artif. Cells Nanomed. Biotechnol. 2019, 47, 1947-1960. [CrossRef] [PubMed]

175. Yu, X.A.; Lu, M.; Luo, Y.; Hu, Y.; Zhang, Y.; Xu, Z.; Gong, S.; Wu, Y.; Ma, X.N.; Yu, B.Y.; et al. A cancer-specific activatable theranostic nanodrug for enhanced therapeutic efficacy via amplification of oxidative stress. Theranostics 2020, 10, 371-383. [CrossRef] [PubMed]

176. Yu, Y.; Zu, C.; He, D.; Li, Y.; Chen, Q.; Chen, Q.; Wang, H.; Wang, R.; Chaurasiya, B.; Zaro, J.L.; et al. pH-dependent reversibly activatable cell-penetrating peptides improve the antitumor effect of artemisinin-loaded liposomes. J. Colloid Interface Sci. 2021, 586, 391-403. [CrossRef] [PubMed]

177. Wang, Z.; Yu, Y.; Ma, J.; Zhang, H.; Zhang, H.; Wang, X.; Wang, J.; Zhang, X.; Zhang, Q. LyP-1 Modification To Enhance Delivery of Artemisinin or Fluorescent Probe Loaded Polymeric Micelles to Highly Metastatic Tumor and Its Lymphatics. Mol. Pharm. 2012, 9, 2646-2657. [CrossRef]

178. Manjili, H.K.; Malvandi, H.; Mousavi, M.S.; Attari, E.; Danafar, H. In vitro and in vivo delivery of artemisinin loaded PCL-PEGPCL micelles and its pharmacokinetic study. Artif. Cells Nanomed. Biotechnol. 2018, 46, 926-936. [CrossRef]

179. Nosrati, H.; Barzegari, P.; Danafar, H.; Kheiri Manjili, H. Biotin-functionalized copolymeric PEG-PCL micelles for in vivo tumour-targeted delivery of artemisinin. Artif. Cells Nanomed. Biotechnol. 2019, 47, 104-114. [CrossRef]

180. Meng, H.; Xu, K.; Xu, Y.; Luo, P.; Du, F.; Huang, J.; Lu, W.; Yu, J.; Liu, S.; Muir, B. Nanocapsules based on mPEGylated artesunate prodrug and its cytotoxicity. Colloids Surf. B Biointerfaces 2014, 115, 164-169. [CrossRef]

181. Sun, Q.; Teong, B.; Chen, I.F.; Chang, S.J.; Gao, J.; Kuo, S.M. Enhanced apoptotic effects of dihydroartemisinin-aggregated gelatin and hyaluronan nanoparticles on human lung cancer cells. J. Biomed. Mater. Res. Part B Appl. Biomater. 2014, 102, 455-462. [CrossRef]

182. Ma, W.; Xu, A.; Ying, J.; Li, B.; Jin, Y. Biodegradable core-shell copolymer-phospholipid nanoparticles for combination chemotherapy: An in vitro study. J. Biomed. Nanotechnol. 2015, 11, 1193-1200. [CrossRef]

183. Phung, C.D.; Le, T.G.; Nguyen, V.H.; Vu, T.T.; Nguyen, H.Q.; Kim, J.O.; Yong, C.S.; Nguyen, C.N. PEGylated-Paclitaxel and Dihydroartemisinin Nanoparticles for Simultaneously Delivering Paclitaxel and Dihydroartemisinin to Colorectal Cancer. Pharm. Res. 2020, 37, 129. [CrossRef]

184. Liu, L.; Wei, Y.; Zhai, S.; Chen, Q.; Xing, D. Dihydroartemisinin and transferrin dual-dressed nano-graphene oxide for a $\mathrm{pH}$-triggered chemotherapy. Biomaterials 2015, 62, 35-46. [CrossRef] [PubMed]

185. Liu, K.; Dai, L.; Li, C.; Liu, J.; Wang, L.; Lei, J. Self-assembled targeted nanoparticles based on transferrin-modified eight-armpolyethylene glycol-dihydroartemisinin conjugate. Sci. Rep. 2016, 6, 29461. [CrossRef] [PubMed]

186. Ji, P.; Huang, H.; Yuan, S.; Wang, L.; Wang, S.; Chen, Y.; Feng, N.; Veroniaina, H.; Wu, Z.; Wu, Z.; et al. ROS-Mediated Apoptosis and Anticancer Effect Achieved by Artesunate and Auxiliary Fe(II) Released from Ferriferous Oxide-Containing Recombinant Apoferritin. Adv. Healthc. Mater. 2019, 8, 1900911. [CrossRef]

187. He, Z.; Su, H.; Shen, Y.; Shi, W.; Liu, X.; Liu, Y.; Zhang, F.; Zhang, Y.; Sun, Y.; Ge, D. Poly(norepinephrine)-coated FeOOH nanoparticles as carriers of artemisinin for cancer photothermal-chemical combination therapy. RSC Adv. 2019, 9, 9968-9982. [CrossRef]

188. Dong, L.; Wang, C.; Zhen, W.; Jia, X.; An, S.; Xu, Z.; Zhang, W.; Jiang, X. Biodegradable iron-coordinated hollow polydopamine nanospheres for dihydroartemisinin delivery and selectively enhanced therapy in tumor cells. J. Mater. Chem. B 2019, 7, 6172-6180. [CrossRef] [PubMed]

189. Hao, D.L.; Xie, R.; De, G.J.; Yi, H.; Zang, C.; Yang, M.Y.; Liu, L.; Ma, H.; Cai, W.Y.; Zhao, Q.H.; et al. PH-responsive artesunate polymer prodrugs with enhanced ablation effect on rodent xenograft colon cancer. Int. J. Nanomed. 2020, 15, 1771-1786. [CrossRef]

190. Halevas, E.; Mavroidi, B.; Kokotidou, C.; Mitraki, A.; Pelecanou, M.; Sagnou, M. Advanced bis-MPA hyperbranched dendritic nanocarriers of artemisinin with anticancer potential. J. Nanoparticle Res. 2021, 23, 135. [CrossRef]

191. Zhang, H.; Hou, L.; Jiao, X.; Ji, Y.; Zhu, X.; Zhang, Z. Transferrin-mediated fullerenes nanoparticles as Fe2+-dependent drug vehicles for synergistic anti-tumor efficacy. Biomaterials 2015, 37, 353-366. [CrossRef]

192. Emami, J.; Yousefian, H.; Sadeghi, H. Targeted Nanostructured Lipid Carrier for Brain Delivery of Artemisinin: Design, Preparation, Characterization, Optimization and Cell Toxicity. J. Pharm. Pharm. Sci. 2018, 21, 225s-241s. [CrossRef]

193. Asgharkhani, E.; Najmafshar, A.; Chiani, M. Artemisinin (ART) drug delivery using mixed non-ionic surfactants and evaluation of their efficiency in different cancer cell lines. Int. J. Drug Deliv. Technol. 2014, 4, 67-71. [CrossRef]

194. Dwivedi, A.; Mazumder, A.; du Plessis, L.; du Preez, J.L.; Haynes, R.K.; du Plessis, J. In vitro anti-cancer effects of artemisone nano-vesicular formulations on melanoma cells. Nanomed. Nanotechnol. Biol. Med. 2015, 11, 2041-2050. [CrossRef] [PubMed]

195. Mirzaei-Parsa, M.J.; Najafabadi, M.R.H.; Haeri, A.; Zahmatkeshan, M.; Ebrahimi, S.A.; Pazoki-Toroudi, H.; Adel, M. Preparation, characterization, and evaluation of the anticancer activity of artemether-loaded nano-niosomes against breast cancer. Breast Cancer 2020, 27, 243-251. [CrossRef] [PubMed]

196. Wilczewska, A.Z.; Niemirowicz, K.; Markiewicz, K.H.; Car, H. Nanoparticles as drug delivery systems. Pharmacol. Rep. 2012, 64, 1020-1037. [CrossRef]

197. Faraji, A.H.; Wipf, P. Nanoparticles in cellular drug delivery. Bioorg. Med. Chem. 2009, 17, 2950-2962. [CrossRef]

198. Kato, Y.; Ozawa, S.; Miyamoto, C.; Maehata, Y.; Suzuki, A.; Maeda, T.; Baba, Y. Acidic extracellular microenvironment and cancer. Cancer Cell Int. 2013, 13, 89. [CrossRef] 
199. Qi, S.-S.; Sun, J.-H.; Yu, H.-H.; Yu, S.-Q. Co-delivery nanoparticles of anti-cancer drugs for improving chemotherapy efficacy. Drug Deliv. 2017, 24, 1909-1926. [CrossRef]

200. Zhang, Y.J.; Gallis, B.; Taya, M.; Wang, S.; Ho, R.J.Y.; Sasaki, T. pH-Responsive Artemisinin Derivatives and Lipid Nanoparticle Formulations Inhibit Growth of Breast Cancer Cells In Vitro and Induce Down-Regulation of HER Family Members. PLoS ONE 2013, 8, e59086. [CrossRef]

201. Heuer-Jungemann, A.; Feliu, N.; Bakaimi, I.; Hamaly, M.; Alkilany, A.; Chakraborty, I.; Masood, A.; Casula, M.F.; Kostopoulou, A.; Oh, E.; et al. The Role of Ligands in the Chemical Synthesis and Applications of Inorganic Nanoparticles. Chem. Rev. 2019, 119, 4819-4880. [CrossRef]

202. Pugazhendhi, A.; Edison, T.N.J.I.; Karuppusamy, I.; Kathirvel, B. Inorganic nanoparticles: A potential cancer therapy for human welfare. Int. J. Pharm. 2018, 539, 104-111. [CrossRef]

203. Wu, Y.; Zeng, Q.; Qi, Z.; Deng, T.; Liu, F. Recent Progresses in Cancer Nanotherapeutics Design Using Artemisinins as Free Radical Precursors. Front. Chem. 2020, 8, 472. [CrossRef]

204. Duan, Y.; Qin, W.; Suo, F.; Zhai, X.; Guan, Y.; Wang, X.; Zheng, Y.; Liu, H. Design, synthesis and in vitro evaluation of stilbene derivatives as novel LSD1 inhibitors for AML therapy. Bioorg. Med. Chem. 2018, 26, 6000-6014. [CrossRef] [PubMed]

205. Aderibigbe, B.A. Design of drug delivery systems containing artemisinin and its derivatives. Molecules 2017, 22, 323. [CrossRef] [PubMed]

206. Akbarzadeh, A.; Rezaei-Sadabady, R.; Davaran, S.; Joo, S.W.; Zarghami, N.; Hanifehpour, Y.; Samiei, M.; Kouhi, M.; Nejati-Koshki, K. Liposome: Classification, preparation, and applications. Nanoscale Res. Lett. 2013, 8, 102. [CrossRef] [PubMed]

207. Sunderland, C.J.; Steiert, M.; Talmadge, J.E.; Derfus, A.M.; Barry, S.E. Targeted nanoparticles for detecting and treating cancer. Drug Dev. Res. 2006, 67, 70-93. [CrossRef]

208. Sur, S.; Rathore, A.; Dave, V.; Reddy, K.R.; Chouhan, R.S.; Sadhu, V. Recent developments in functionalized polymer nanoparticles for efficient drug delivery system. Nano-Struct. Nano-Objects 2019, 20, 100397. [CrossRef]

209. Fiorito, S.; Serafino, A.; Andreola, F.; Togna, A.; Togna, G. Toxicity and biocompatibility of carbon nanoparticles. J. Nanosci. Nanotechnol. 2006, 6, 591-599. [CrossRef] [PubMed]

210. Liu, F.; Cheng, Y.; Tan, J.; Li, J.; Cheng, H.; Hu, H.; Du, C.; Zhao, S.; Yan, Y.; Liu, M. Carbon Nanomaterials With Hollow Structures: A Mini-Review. Front. Chem. 2021, 9, 668336. [CrossRef]

211. Cha, C.; Shin, S.R.; Annabi, N.; Dokmeci, M.R.; Khademhosseini, A. Carbon-Based Nanomaterials: Multifunctional Materials for Biomedical Engineering. ACS Nano 2013, 7, 2891-2897. [CrossRef]

212. Tamjidi, F.; Shahedi, M.; Varshosaz, J.; Nasirpour, A. Nanostructured lipid carriers (NLC): A potential delivery system for bioactive food molecules. Innov. Food Sci. Emerg. Technol. 2013, 19, 29-43. [CrossRef]

213. Attama, A.A.; Umeyor, C.E. The use of solid lipid nanoparticles for sustained drug release. Ther. Deliv. 2015, 6, 669-684. [CrossRef]

214. Ghasemiyeh, P.; Mohammadi-Samani, S. Solid lipid nanoparticles and nanostructured lipid carriers as novel drug delivery systems: Applications, advantages and disadvantages. Res. Pharm. Sci. 2018, 13, 288-303. [PubMed]

215. Hanafy, N.; El-Kemary, M.; Leporatti, S. Micelles Structure Development as a Strategy to Improve Smart Cancer Therapy. Cancers 2018, 10, 238. [CrossRef] [PubMed] 